\title{
Artificial Intelligence and Mathematical Modelling of the Drying Kinetics of Pharmaceutical Powders
}

\author{
S. Keskes, ${ }^{a, b *}$ S. Hanini, ${ }^{b}$ M. Hentabli, ${ }^{a, b}$ and M. Laidi ${ }^{b}$ \\ a Laboratory Quality Control, Physico-Chemical Department, SAIDAL of Médéa, Algeria \\ ${ }^{\mathrm{b}}$ Laboratory of Biomaterials and Transport Phenomena (LBMPT), Faculty of Technology, \\ University Yahia Fares of Médéa, Algeria
}

\begin{abstract}
The study aims at modelling the drying kinetics of a pharmaceutical powder with active ingredient Candesartan Cilexetil. The kinetics was carried out in a vacuum dryer at different temperature levels, pressure, initial mass, and water content. The effect of some operating parameters on the drying time was studied. The modelling of drying times was based on the use of experimental design method. The data obtained were adjusted using 17 semi-empirical models, one proposed, a static ANN and DA_SVMR, regrouping all studied kinetics. The proposed model and DA_SVMR model were chosen as the most appropriate to describe the drying kinetics.
\end{abstract}

\section{Keywords}

Dragonfly algorithm, support vector machine regression (DA_SVMR), artificial neural network (ANN), mathematical modelling, drying kinetics, vacuum drying, Candesartan Cilexetil

\section{Introduction}

The drying engineering process plays an important role in improving the quality of the final product in many production processes, such as in the pharmaceutical industry. The drying process aims primarily at ensuring the conservation of certain pharmaceutical products, reducing their weight in order to facilitate carrying or solving certain issues, such as the caking of wet powders, and the contamination that causes corrosion due to the solvent or chemical degradation by slow hydrolysis. ${ }^{1}$ The selection of a suitable dryer depends on the properties of the active ingredient, taking into consideration the heat-sensitivity of pharmaceutical powders. Numerous researchers have studied the drying time of various powders under different type of dryers, in order to investigate the influence of many operating conditions, such as vacuum pressure, temperature, dielectric loss factor, and moisture content. ${ }^{2-4}$

Due to several limitations, such as many hypotheses, complex and highly nonlinear behaviours, multivariable interaction, etc., it is difficult to obtain an exact representative phenomenological model using conventional methods to fit and control the drying process. Thus, it is required to develop sophisticated methods to deal with all the above limitations..$^{5,6}$

Several studies have shown growing interest in the application of artificial intelligence-based methods in modelling and control of non-linear behaviour drying process. ${ }^{7}$ Moreover, a limited number of researchers have focused on the modelling of quality indicators of pharmaceutical powders by means of machine learning techniques (SVMR). SVMR

${ }^{*}$ Corresponding author: Sonia Keskes, PhD

e-mail: soniakrispo@hotmail.com modelling technique is known for its simplicity, optimisation adaptability, and handling the complex parameters. ${ }^{8}$

Several researchers have proposed mathematical models to describe the phenomenon of change in water content, heat transfer, and mass in drying. The equations can be theoretical, semi-theoretical, and empirical models. ${ }^{9,33}$ The first of them only contains the internal resistance to mass transfer, ${ }^{10}$ while others consider external resistance to mass transfer between product and air. ${ }^{11}$ Theoretical models clearly explain the drying behaviour of the product and can be used in all process conditions, although they involve many hypotheses causing considerable errors. ${ }^{12}$ The most used theoretical models are derived from diffusion. In the same way, semi-theoretical models are generally derived from Fick's second law and modifications of its simplified forms (other semi-theoretical models are derived from Newton's law of cooling). They are simpler and need fewer assumptions because of the use of some experimental results. On the other hand, they are only valid under the conditions of the applied process. ${ }^{13}$ Empirical models have similar characteristics to semi-empirical models. They strongly depend on the experimental conditions and give limited information on the drying behaviour of the product. $^{11}$

\section{Experimental}

The objective of this study was to experimentally determine the vacuum drying process time and modelling of drying kinetics of an active ingredient Candesartan Cilexetil under certain operating conditions. Furthermore, the obtained model of drying kinetics was investigated by different approaches. 
Table 1 - Domain of studied factors

\begin{tabular}{c|l|c|c|c|c|c}
\hline \multirow{2}{*}{ Variable category } & \multicolumn{1}{|c|}{ Factors } & Unit & Domain & STD & Variance & \multicolumn{1}{c}{ KURTOSIS } \\
\hline \multirow{3}{*}{ Input } & temperature $/ T$ & ${ }^{\circ} \mathrm{C}$ & {$[40-60]$} & 8.07 & 65.060 & -1.4593 \\
\cline { 2 - 7 } & pressure $/ p$ & bar & {$[0.4-0.8]$} & 0 & 0.0274 & -1.540 \\
\cline { 2 - 7 } & initial moisture $/ M_{0}$ & $\%$ & {$[10-20]$} & 4.03 & 16.265 & -1.459 \\
\cline { 2 - 7 } & initial mass $/ m_{0}$ & $\mathrm{~g}$ & {$[0.5-1.5]$} & 0.5 & 0.1621 & -1.459 \\
\hline \multirow{2}{*}{ Output } & time $/ \mathrm{t}$ & min & {$[4-42]$} & 8.66 & 75.021 & -0.205 \\
\hline
\end{tabular}

\subsection{Experimental procedure and design of the drying process}

The experimental study was conducted in the Quality Control Laboratory SAIDAL of Médéa, and the modelling part was carried out in the Laboratory of Biomaterials and Phenomena of Transport at the University of Médéa. It was conducted in a vacuum dryer where the effect of four operating parameters, including temperature $\left(T=40-60{ }^{\circ} \mathrm{C}\right)$, pressure ( $p=0.4-0.8$ bar), initial mass $\left(m_{0}=0.5-1.5 \mathrm{~g}\right)$, and initial water content $(M=10-20 \%)$ on the drying time where evaluated and optimised by means of a response surface methodology (RSM) that is based on a full factorial central composite face-centred (CCF) design. In this approach, four factors with three levels $\left(3^{4}\right)$ for each factor were considered, leading to 81 tests, plus 3 experiments for the reproducibility of the model. Table 1 shows the domain of these factors.

The output results (time) were fitted to a second-order polynomial equation (quadratic model), according to the model in Eq. (1).

$y=a_{0}+\sum a_{i} x_{i}+\sum a_{i j} x_{i} x_{j}+\ldots+\sum a_{i i} x_{i}^{2}+a_{i j \ldots \ldots z} x_{i} x_{j} \ldots \ldots x_{z}(1)$

where $y$ is the answer or the magnitude of interest. This is measured during the experiment and obtained with a given precision. $x_{\mathrm{i}}$ represents the level assigned to factor $i$ by the experimenter to perform a test. This value is perfectly known. It is even supposed that this level is determined without error (classical assumption of regression). $a_{0}, a_{i}, a_{i j}$ $a_{\mathrm{ii}}$ are the coefficients of the mathematical model adopted a priori. They are not known, and must be calculated from the results of the experiments. The MODEL software was used to produce diagrams, experiments, and the model.

The thin layer drying process was carried out in a vacuum oven using an aluminium sheet of equal contact surface (54 $\mathrm{mm} \times 56 \mathrm{~mm}$ ). The thickness of the sample varied from 1 to $4 \mathrm{~mm}$. The time intervals varied with temperature and pressure. The initial moisture was determined using Karl Fischer. Table 2 specifies the active ingredient used in this work.

Table 2 - Specification of the powder ready for pharmaceutical use (European Pharmacopoeia, 2017)

\begin{tabular}{l|c}
\hline Chemical formula & $\mathrm{C}_{33} \mathrm{H}_{34} \mathrm{~N}_{6} \mathrm{O}_{6}$ \\
\hline Molecular weight $/ \mathrm{g} \mathrm{mol}^{-1}$ & 610.67 \\
\hline Diameter & $\leq 6 \mu \mathrm{m}$ \\
\hline Water content (norm) & $\geq 0.3 \%$ \\
\hline Melting point & $157-160{ }^{\circ} \mathrm{C}$ \\
\hline
\end{tabular}

\subsection{Mathematical modelling}

The moisture ratio of the Candesartan Cilexetil samples during the thin layer vacuum drying experiments was obtained using the Eq. (2):

$$
M_{\mathrm{R}}=\frac{M_{\mathrm{t}}-M_{\mathrm{e}}}{M_{0}-M_{\mathrm{e}}}
$$

where $M_{\mathrm{t}}, M_{0}$, and $M_{\mathrm{e}}$ are moisture content at any time of the drying process, initial, and equilibrium moisture content, respectively. The equilibrium moisture content is relatively negligible compared to $M_{\mathrm{t}}$ and $M_{0}$.

Table 3 summarizes 17 models in the literature and the proposed model. The obtained drying curves were processed for drying rates to find the most suitable model among the eighteen different models. Mathematical model parameters were optimised using hybrid program (genetic-algorithm-nonlinear-curve-fitting). We were mostly interested in the application of genetic algorithms coupled with nonlinear fitting methods (hybrid program) to obtain model coefficients (Fig. 1). To determine the coefficients, MATLAB R2009a software was used. 
Table 3 - Mathematical thin-layer models applied to moisture ratio values

\begin{tabular}{|c|c|c|c|}
\hline $\mathrm{N}^{\circ}$ & Model & Equation & Refs \\
\hline 1. & Newton & $M_{R}=\exp (-k t)$ & 14 \\
\hline 2. & Page & $M_{R}=\exp \left(-k t^{n}\right)$ & 15 \\
\hline 3. & Modified Page II & $M_{R}=\exp \left(-(k t)^{n}\right)$ & 16 \\
\hline 4. & Henderson and Pabis & $M_{R}=a \exp \left(-k t^{n}\right)$ & 17 \\
\hline 5. & Yagcioglu & $M_{\mathrm{R}}=\mathrm{a} \exp (-k t)+c$ & 18 \\
\hline 6. & Two_term & $M_{R}=a \exp (-k t)+b \exp \left(-k_{1} t\right)$ & 19 \\
\hline 7. & Two_term exponential & $M_{R}=a \exp (-k t)+(1-a) \exp (-k a t)$ & 19 \\
\hline 8. & Wang and Singh & $M_{\mathrm{R}}=1+a t+b t^{2}$ & 21 \\
\hline 9. & Diffusion approach & $M_{R}=a \exp (-k t)+(1-a) \exp (-k b t)$ & 21 \\
\hline 10. & Verma et al. & $M_{R}=a \exp (-k t)+(1-a) \exp (-g t)$ & 23 \\
\hline 11. & Modified Henderson and Pabis & $M_{R}=a \exp (-k t)+b \exp \left(-k_{1} t\right)+c \exp (-n t)$ & 24 \\
\hline 12. & Simplified Fick's diffusion & $M_{R}=\operatorname{aexp}\left(-k\left(t / L^{2}\right)\right)$ & 24 \\
\hline 13. & Modifide Page II & $M_{R}=\exp \left(-k\left(t / L^{2}\right)^{n}\right)$ & 26 \\
\hline 14. & Midilli and Kucuk & $M_{R}=a \exp \left(-k t^{n}\right)+b t$ & 27 \\
\hline 15. & Demir etal. & $M_{R}=a \exp \left(-k t^{n}\right)+b$ & 28 \\
\hline 16. & Weibull & $M_{R}=\exp \left(-(t / a)^{n}\right)$ & 29 \\
\hline 17. & Hii & $M_{R}=a \exp \left(-k t^{n}\right)+b \exp \left(-k_{1} t^{n}\right)$ & 30 \\
\hline 18. & Proposed model & $M_{R}=a \exp (-k t)+b \exp \left(-k t^{1 / n}\right)+c$ & In this study \\
\hline
\end{tabular}

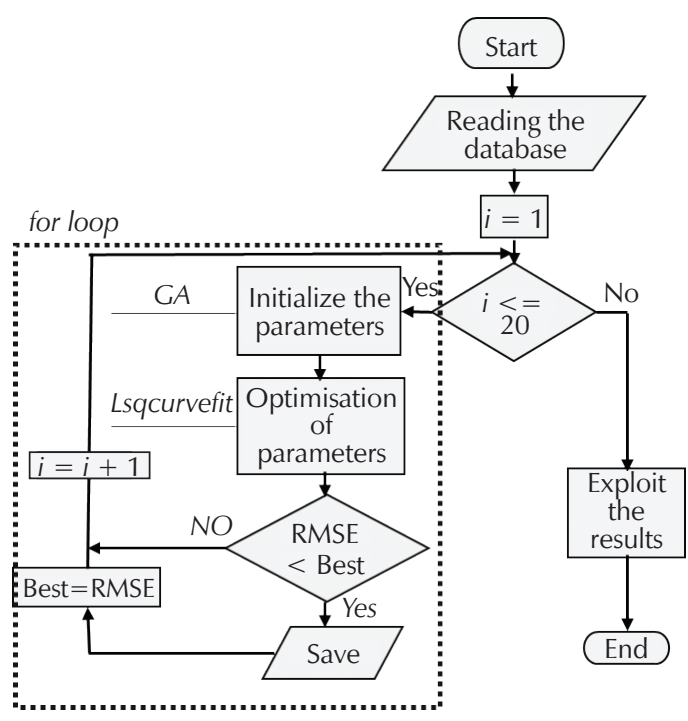

Fig. 1 - Hybrid program for determination of the model coefficients (genetic-algorithm-nonlinear-curve-fitting)
The best model was chosen using the analysis of statistical parameters, such as the coefficient of determination $\left(R^{2}\right)$, the chi-square $\left(\chi^{2}\right)$, and square root of the mean square error (RMSE). These parameters were calculated by the form Eqs. (3-5).

$$
\begin{array}{r}
R^{2}=1-\frac{\sum_{i=1}^{N}\left(M_{\text {Rcal }}-M_{\text {Rexp }}\right)^{2}}{\sum_{i=1}^{N}\left(M_{\text {Rexp }}-\bar{M}_{\text {Rexp }}\right)^{2}} \\
X^{2}=\frac{\sum_{i=1}^{n}\left(M_{\text {Rexp }, i}-M_{\text {R cal }, i}\right)^{2}}{N-n} \\
\text { RMSE }=\sqrt{\frac{1}{N} \sum_{i=1}^{N}\left(M_{\text {Rexp }}-M_{\text {Rcal }}\right)^{2}}
\end{array}
$$

\subsection{Artificial neural network}

The idea of artificial neural networks was inspired by the way biological neurons proceed information. This concept 
is utilised to carry out software simulations for the massively parallel processes, which involve processing elements that are interconnected in the network architecture. Learning in the human brain occurs in a network of neurons that are interconnected by axons, synapses, and dendrites. A variable synaptic resistance affects the run of information between two biological neurons. The artificial neuron receives inputs that are analogous to the electrochemical impulses that the dendrites of biological neurons receive from other neurons. Therefore, ANN can be considered a network of neurons, which are processing elements and weighted connections/weighing connections. The connections and weights are analogous to axons and synapses in the human brain, respectively. When simulating human brain analytical function, ANN has an intrinsic ability to learn and recognize highly non-linear and complex relationships by experience. ${ }^{36}$ The procedure of weight adjustment is called back-propagation. A simplified procedure for the learning process of ANNs is summarised according to the following steps:

Step 1: Providing the network with training data consisting of input variables and target outputs.

Step 2: Evaluating the agreement of the network output with the target outputs.

Step 3: Adapting the connection weights between the neurons so the network produces better approximations of the desired target outputs.

Step 4: Continuing the process of adjusting the weights until some desired level of accuracy is achieved.

The modelling and simulation of a drying process goes by obtaining the data on how a drying process will behave without doing practical experiments. ${ }^{37}$ The ANN implementation is composed of several stages that are thoroughly explained and summarised in the flow chart shown in Fig. 2. ${ }^{38,39}$ All ANN calculations were conducted using free MATLAB R2009b software installed in Windows.

\subsection{Support vector regression}

Support vector machine regression (SVMR) analysis is a common machine learning tool for regression. It was first identified by Vladimir Vapnik and his colleagues in 1992. ${ }^{40}$ SVM regression is considered a nonparametric technique because it relies on kernel functions (Table 4). This kernel function is included in MATLAB toolbox.

Table 4 - Kernel function

\begin{tabular}{c|c}
\hline Kernel name & Kernel function \\
\hline linear & $x^{\top} z$ \\
\hline gaussian; RBF & $\exp \left(\frac{x-z}{2 \sigma^{2}}\right)$ \\
\hline polynomial & $\left(1+x^{\top} z\right)^{p} p=1,2,3 \ldots$ \\
\hline
\end{tabular}

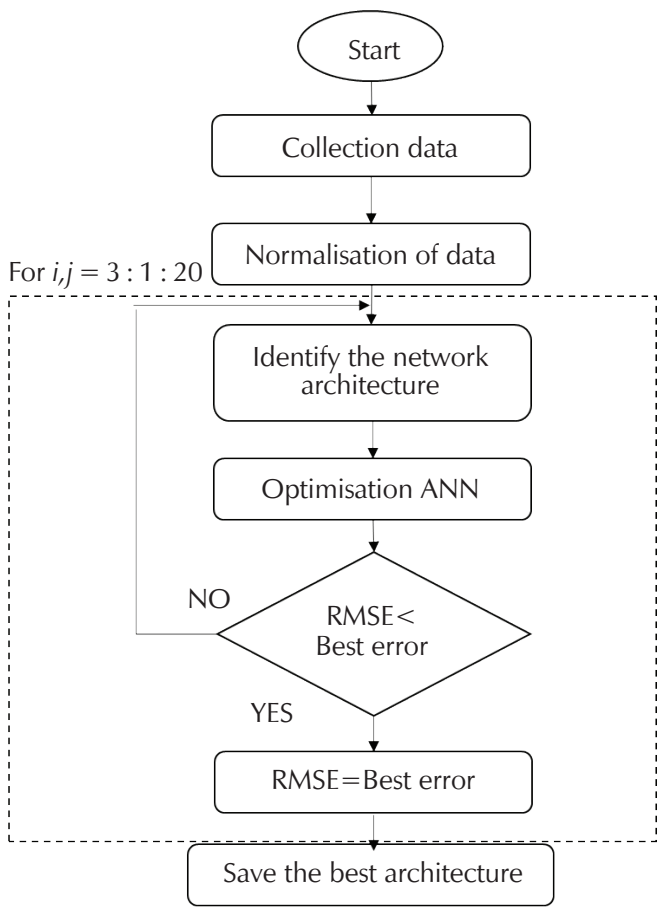

Fig. 2 - Flow chart of ANN training processes

The dual formula for nonlinear SVM regression replaces the inner product of the predictors $\left(x^{\top} z\right)$ with the corresponding element of the gram matrix nonlinear SVM regression to find the coefficients that minimize. ${ }^{41}$

$$
\begin{aligned}
L(\alpha)= & \frac{1}{2} \sum_{i=1}^{N} \sum_{j=1}^{N}\left(\alpha_{i}-\alpha_{i}^{*}\right)\left(\alpha_{j}-\alpha_{j}^{*}\right) G\left(x_{i}, x_{j}\right)+ \\
& +\varepsilon \sum_{i=1}^{N}\left(\alpha_{i}-\alpha_{i}^{*}\right)-\sum_{i=1}^{N} y\left(\alpha_{j}-\alpha_{j}^{*}\right)
\end{aligned}
$$

The function used to predict new values relies only on the media vectors:

$$
\left.f(x)=\sum_{n=1}^{N} \alpha_{n}-\alpha_{n^{*}}\right) G\left(x_{n}, x\right)+b
$$

The proposed model is based on SVMR learning algorithm, associated with DA algorithm for optimisation of its hyper-parameters. The division proportions of the data for training and test, along with the ranges of the hyper-parameters are the same as those for ANN. The steps leading to the development of the optimal DA-SVMR hybrid algorithm are illustrated in the flowchart presented in Fig. 3.

\section{Results and discussion}

\subsection{Experimental design}

The Table S1 (supplementary material) shows the experimental data for drying the powder. In this study, MODDE software (for Design of Experiments and Quality by Design analysis) was used to calculate the interaction effects and 


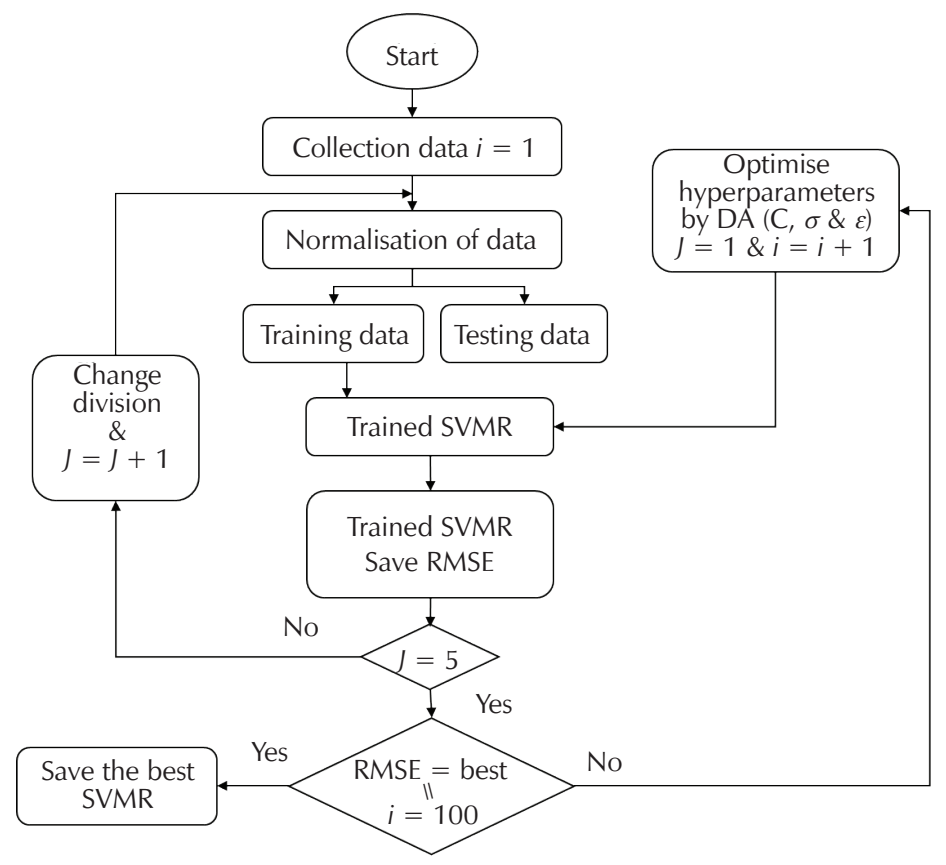

Fig. 3 - Flowchart of the proposed algorithm for trained (DA-SVMR)

4D Response contour of time (min)-complplan (MLR)

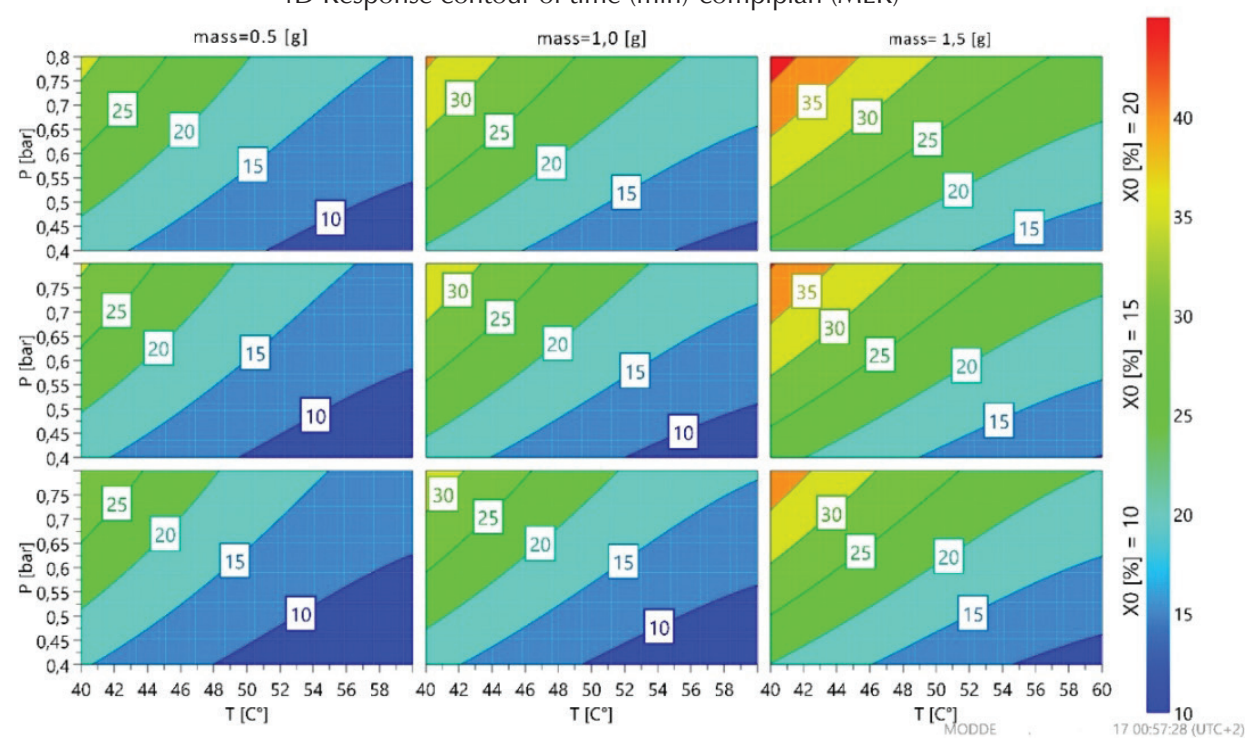

Fig. 4 - Iso-response curves of the modelling in drying time

the optimal parameter coefficients of the following second-order fitting model. In this model Eq. (12), a coefficient with a plus sign means that the factor has a synergetic effect on the drying time. According to this study, temperature is shown as the most influential parameter on drying process time. Interactions of statistical values $p<0.05$ are neglected, and the model obtained by the experimental design was provided by the following form Eq. (8):

$$
\begin{aligned}
\text { Temps }= & 77.7645-11.6935 m_{0}+0.2741 M_{0}+ \\
& +63.4722 p-2.9459 T+6.0319 m_{0}{ }^{2}+ \\
& +0.0273 T^{2}+10.5556 m_{0} p-0.8472 p T
\end{aligned}
$$

The iso-response curves are graphical representations of all factors at all levels. The results of the interactions between four independent variables and the dependent variable are shown in Fig. 4. The software divided the zones according to the complete drying time in all the factors studied.

The results of the analysis of variance (ANOVA) summarised to test the validity of the model are presented in Table 5 . The results were evaluated using descriptive statistical analysis, such as p-value, F-value, degree of freedom $\left(d_{\mathrm{f}}\right)$, and the coefficient of determination $\left(R^{2}\right)$.

As shown in Table 6 , a low probability value $(p=0.000)$ indicates that the model was highly significant. The high 
Table 5 - Analysis of variance of model (ANOVA)

\begin{tabular}{c|c|c|c|c|c|c}
\hline & Degree of freedom & Sum of squares & Mean squares & F-value & $p$-value & SD \\
\hline model & 8 & 6046.89 & 755.861 & 358.126 & $\mathbf{0 . 0 0 0}$ & 27.4929 \\
\hline residual & 75 & 158.295 & 2.1106 & & 1.45279 \\
\hline pure error & 3 & 23.5675 & 7.85583 & & 2.80283 \\
\hline total & 84 & 36199.5 & 430.946 & & \\
\hline & $R^{2}{ }_{\text {adj }}=$ & 0.972 & $R^{2}=$ & 0.974 & \\
\hline
\end{tabular}

value of the coefficient of determination $\left(R^{2}=0.974\right)$ indicates a high reliability of the model.

\subsection{Mathematical modelling of kinetics}

For the mathematical modelling, the thin-layer drying equations, presented in Table 3, were tested to illustrate the drying curves of Candesartan Cilexetil (Figs. 5-7) under the nine experimental conditions. Among these experiments, nine kinetics at temperatures $\left(60,50, \& 40{ }^{\circ} \mathrm{C}\right)$, mass $(0.5,1$, and $1.5 \mathrm{~g})$, initial water content $10 \%$, and pressure 0.8 bar (Figs. 5-7) were selected to apply the modelling and physical description.

Tables (S2-S4 \& 6) report the results obtained when modelling the moisture content in thin-layer drying of this active ingredient and the optimised parameters of each model. A comparison between the semi-empirical models and proposed models in terms of RMSE show that the proposed model gives high performance when modelling the moisture content of the Candesartan Cilexetil samples throughout the thin-layer vacuum drying process. The proposed semi-empirical model was chosen as the most appropriate to describe the drying kinetics of the Candesartan Cilexetil powder. It has shown, respectively, a $R^{2}$ which varies from 0.999726 to 0.99999 , and RMSE that varies between 0.077800 and $8.810405 \cdot 10^{-3} \min$ for the nine-kinetics

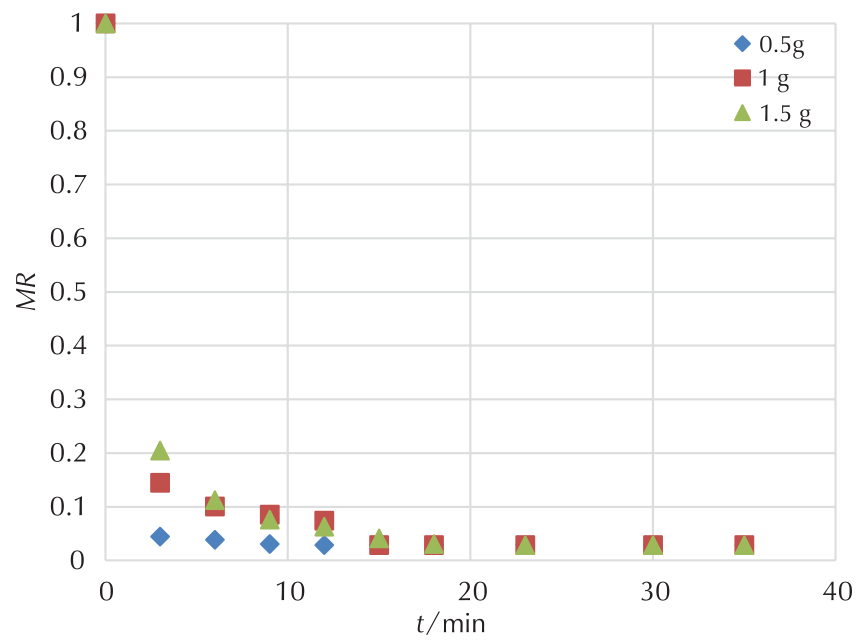

Fig. 5 - Evolution of the moisture ratio $(M R)$ as a function of time at temperatures $60{ }^{\circ} \mathrm{C}$, mass $(0.5,1$, and $1.5 \mathrm{~g})$, and initial water content $10 \%$ studied. The results of models 15 and 11 were close, but proposed model is preferable.

Fig. 8 represents evolution of the moisture ratio $(M R)$ exp calculated by proposed model as a function of time at temperatures $\left(40,50\right.$, and $\left.60{ }^{\circ} \mathrm{C}\right)$ and mass $(0.5,1$, and $1.5 \mathrm{~g})$.

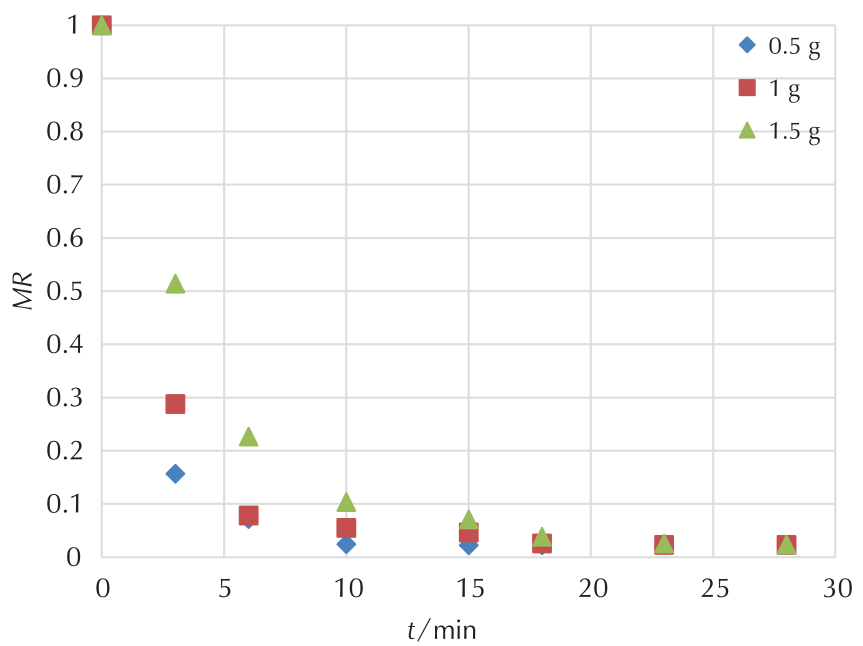

Fig. 6 - Evolution of the moisture ratio $(M R)$ as a function of time at temperatures $50{ }^{\circ} \mathrm{C}$, mass $(0.5,1$, and $1.5 \mathrm{~g})$, and initial water content $10 \%$



Fig. 7 - Evolution of the moisture ratio $(M R)$ as a function of time at temperatures $40{ }^{\circ} \mathrm{C}$, mass $(0.5,1$, and $1.5 \mathrm{~g})$, and initial water content $10 \%$ 
Table 6 - Performance comparison of the best selected models in terms of RMSE

\begin{tabular}{|c|c|c|c|c|}
\hline Initial samples weight & $\mathrm{T} /{ }^{\circ} \mathrm{C}$ & Model $11 \cdot 10^{3}$ & Model $15 \cdot 10^{3}$ & Proposed model $\cdot 10^{3}$ \\
\hline $0.5 \mathrm{~g}$ & $\begin{array}{l}60 \\
50 \\
40\end{array}$ & $\begin{array}{l}2.27120 \\
7.94400 \\
11.6600\end{array}$ & $\begin{array}{l}1.285600 \\
4.194000 \\
7.867000\end{array}$ & $\begin{array}{l}0.158900 \\
0.077800 \\
1.193400\end{array}$ \\
\hline \multicolumn{2}{|l|}{ mean } & 7.29173 & 4.448870 & 0.476700 \\
\hline $1 \mathrm{~g}$ & $\begin{array}{l}60 \\
50 \\
40\end{array}$ & $\begin{array}{l}11.54027 \\
3.977283 \\
4.544892\end{array}$ & $\begin{array}{l}10.27168 \\
07.11189 \\
08.85998\end{array}$ & $\begin{array}{l}8.810405 \\
7.736377 \\
4.145978\end{array}$ \\
\hline \multicolumn{2}{|l|}{ mean } & 6.687483 & 8.747856 & 6.897587 \\
\hline $1.5 \mathrm{~g}$ & $\begin{array}{l}60 \\
50 \\
40\end{array}$ & $\begin{array}{l}8.091835 \\
5.340854 \\
1.891862\end{array}$ & $\begin{array}{l}3.787095 \\
5.526422 \\
3.740056\end{array}$ & $\begin{array}{l}3.755685 \\
5.339153 \\
1.284290\end{array}$ \\
\hline \multicolumn{2}{|l|}{ mean } & 5.108184 & 4.351191 & 3.459709 \\
\hline \multicolumn{2}{|l|}{ Global mean } & 6.362466 & 5.849303 & 3.611332 \\
\hline
\end{tabular}


Fig. 8 - Evolution of the moisture ratio $(M R)$ exp and cal by proposed model as a function of time at temperatures $\left(40,50\right.$, and $\left.60^{\circ} \mathrm{C}\right)$ and mass $(0.5,1$, and $1.5 \mathrm{~g})$ 


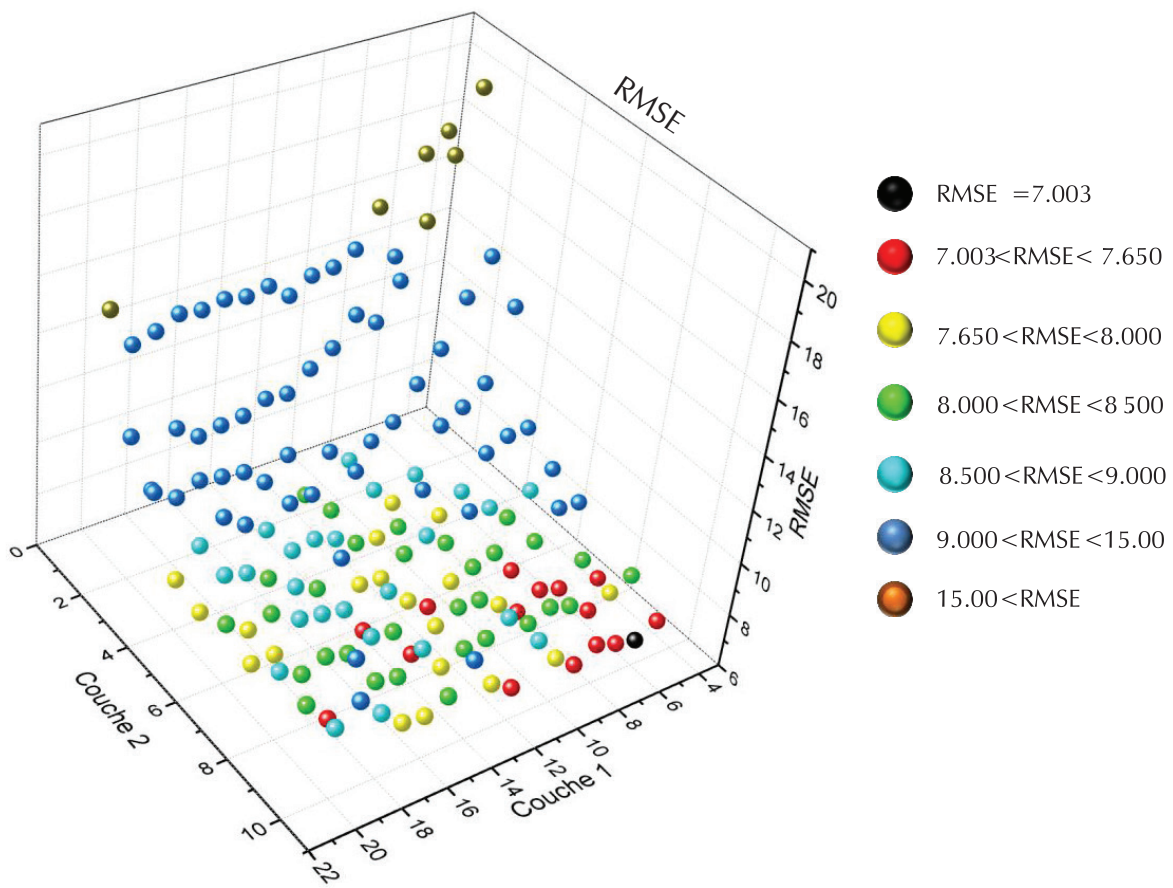

Fig. 9 - Results of neuronal variations in the hidden layers

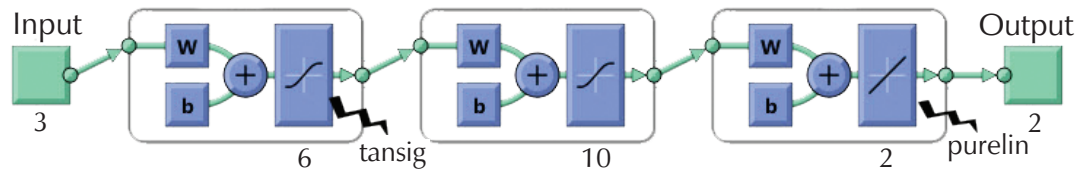

Fig. 10 - Multilayer neural networks for MR calculation

\subsection{Artificial neural network modelling}

There is no rule for choosing the number of neurons in the hidden layer. ${ }^{38}$ In order to obtain the best neuronal structure, the number of neurons on the hidden layers has been optimised. In this study, we started with a hidden layer, varying the number of neurons hidden from 1 to 30, then an ANN with 2 hidden layers was tested where the number of neurons in the first layer ranged from 3 to 20 and the second layer from 1 to 10 neurons, each architecture was repeated 600 times to avoid convergence to the local minimum. Fig. 9 represents the error variation (RMSE) relative to the number of neurons in each hidden layer.

The result of optimisation of ANN, hidden layer 1 and 2 according to err (RMSE). Following the optimisation stage, an MLP with 6 neurons in the first hidden layer and 10 neurons in the second hidden layer, was quite acceptable for moisture content estimation based on the selected inputs mentioned earlier. Fig. 10 shows the architecture of optimised ANN.

To evaluate the predictive ability of a neural model, the latter must be tested for data that have been excluded from the learning base. Therefore, the linear regression of the ANN and the targeted (output) results of the ANN prediction were used. These are easily obtained using the postreg function of MATLAB ${ }^{\circledR}$. Fig. 11 shows the linear re-

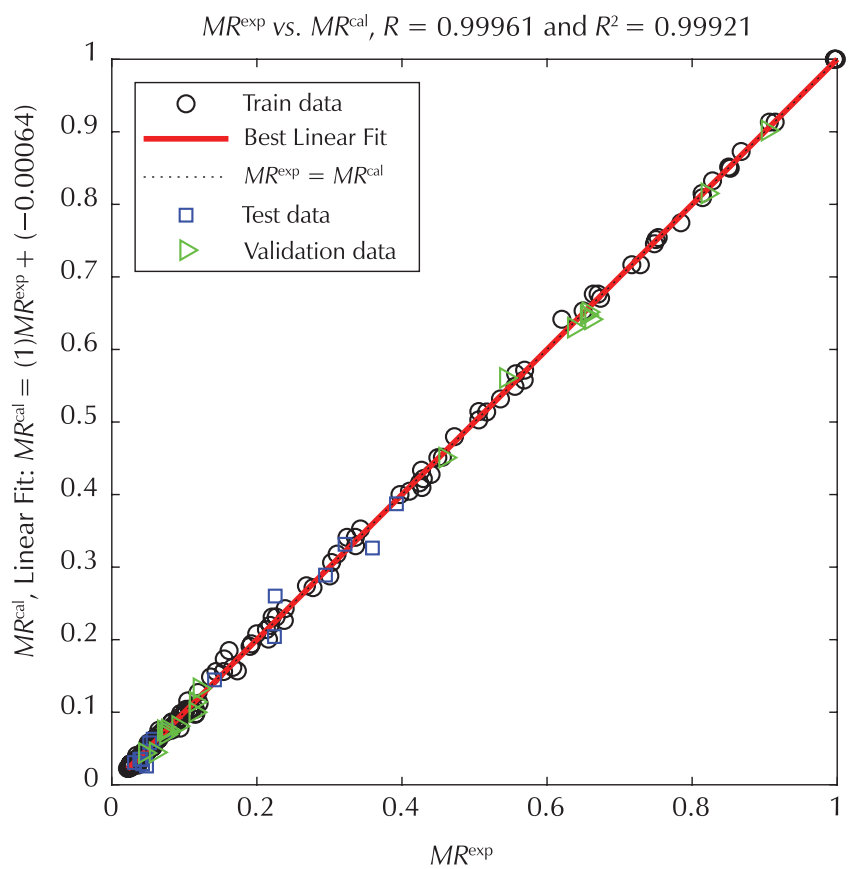

Fig. 11 - Linear $M R$ regressions with $M R^{\exp }(\mathrm{All})$ 
Table 7 - Parameters of the SVMR model

\begin{tabular}{c|c|c|c|c|c|c}
\hline C & $\varepsilon$ & $\gamma$ & Kernel function & $\begin{array}{c}\text { Quantity of support } \\
\text { vectors }\end{array}$ & Cross-validation error & RMSE/- \\
\hline 40.5 & 0.0065 & 0.1576 & Gaussian & $75 \%$ & $8.4 \cdot 10^{-4}$ & 0.0048 \\
\hline
\end{tabular}

gression curve of the reduced water content MR calculated by ANN optimised with the experimental water content for all phases of learning, testing, and validation with a regression vector approaching the ideal [ $\alpha$ (slope), $\beta$ (intercept), $R$ (correlation coefficient), $R^{2}$ (coefficient of determination) $=[1,0.00064,0.99961]$

\subsection{Dragonfly algorithm support vector machine regression (DA-SVMR)}

The optimisation of the SVMR model included the selection of the capacity parameter $C$, the $\varepsilon$-insensitive, loss function, and the corresponding parameters of the kernel function. Firstly, the kernel function should be decided. It defines the sample distribution in the mapping space. Usually, using the kernel function obtains better prediction performance, ${ }^{42}$ and accordingly, it was used as the SVMR model kernel in this study. The kernel used is presented in Table 4, where $\gamma$ is the parameter of the kernel, and $x$ and $z$ are two independent variables. Secondly, the corresponding parameters, i.e., $\gamma$ of the kernel function greatly affects the number of support vectors, which has a close relation with the performance of the SVMR and training time. Many support vectors could produce over-fitting and increase the training time. Additionally, $\gamma$ controls the amplitude of the kernel function, and therefore, controls the generalisation ability of the SVMR. The $\varepsilon$-insensitive parameter prevents the entire training set from meeting the boundary conditions, and therefore allows the possibility of sparsity in the dual formulation's solution. The optimal value depends on the type of noise present in the data, which is usually unknown. Lastly, the effect of the capacity parameter $\mathrm{C}$ was tested. It controls the trade-off between maximising the margin and minimising the training error. If $\mathrm{C}$ is too low, then insufficient stress will be placed on fitting the training data. If $\mathrm{C}$ is much higher than the algorithm, it will overfit the training data. However, Wang et al. ${ }^{43}$ indicated that prediction error was scarcely influenced by $\mathrm{C}$. To make the learning process stable, a large value should be set up for $\mathrm{C}$. Table 7 shows the best obtained parameters.

To optimise the SVMR model parameters, we used the algorithm mentioned in the experimental part. The SVMR model was trained and tested using a pre-processed data $\left(X_{\text {in }}\right)$ on the basis of this proposed expression Eq. (9):

$$
X_{\text {in }}=\sqrt[1 / 0.2]{X_{i}}
$$

A scatter-plot of the observed against experimental data that are based on the SVMR results are depicted in Fig. 12. Results show a satisfactory performance with high determination coefficient of 0.99975 and very low RMSE of 0.0048 .

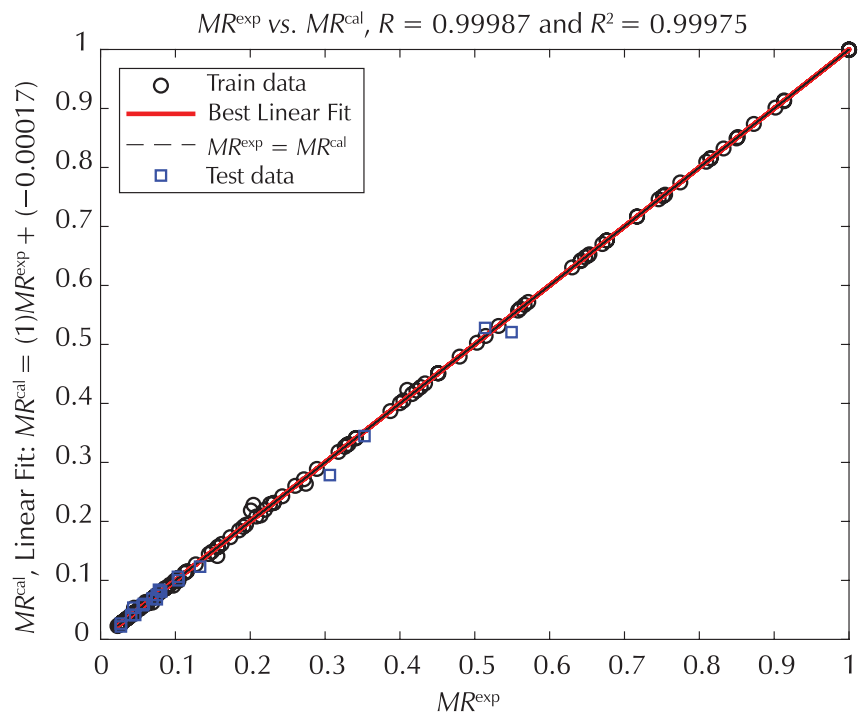

Fig. 12 - Experiment against observed drying time during training and test stage based on DA_SVMR result

\subsection{Comparison between DA_SVMR and ANN models}

The comparison of DASVMR and ANN models is based on the statistical parameters, learning time, and the complexity of the model. Table 8 presents the comparison of the modelling of SVMR and ANN according to the RMSE, $R$, $R^{2}$, number of parameters, and time.

Table 8 - Comparison between DA_SVMR and ANN models

\begin{tabular}{c|c|c|c|c}
\hline Model & RMSE $\cdot 10^{-3}$ & $R$ & $R^{2}$ & $\begin{array}{c}\text { Quantity to } \\
\text { parameters }\end{array}$ \\
\hline ANN & 7.0 & 0.99961 & 0.99921 & 197 \\
\hline DA_SVMR & 4.8 & 0.99987 & 0.99975 & 144 \\
\hline
\end{tabular}

\section{Conclusion}

In light of the findings of this study, the following conclusions were drawn:

- The moisture content data of an active ingredient was experimentally determined throughout the process of vacuum drying under certain operating conditions.

- The obtained data were modelled by means of seventeen well-known semi-empirical models from literature, one semi-empirical model proposed in this work, and neural networks model. 
- The results show that the proposed semi-empirical model demonstrated a higher performance to model the moisture content $(M R)$ of the pharmaceutical powder of Candesartan Cilexétil in the drying process with higher determination coefficient ranging between $\{0.999726-0.99999\}$ and very low RMSE ranging between $\{0.077800-8.810405) \cdot 10^{-3}$.

- In this work, the best model in terms of accuracy, smoothness, and flexibility is the hybrid model DA SVMR.

\section{ACKNOWLEDGEMENTS}

Authors of this article gratefully acknowledge the employees of the SAIDAL of Médéa, Algeria and Laboratory of Biomaterials and Transport Phenomena (LBMPT), Faculty of Technology, University Yahia Fares of Médéa, Algeria, for their help and technical support during this work. Authors declare no conflict of interest.

\section{List of symbols and abbreviations}

$\begin{array}{ll}a_{0}, a_{i}, a_{i j}, a_{i i} & - \text { models parameters } \\ \text { ANN } & \text { - artificial neural network } \\ C, \varepsilon \text {-insensitive, } \gamma & \text { - hyperplane parameters } \\ \text { cal } & - \text { calculated } \\ \text { DA } & - \text { dragonfly algorithm } \\ \text { e } & \text { - thickness of the potato slices, mm } \\ \text { exp } & - \text { experimental } \\ m & - \text { initial mass, gram } \\ M & - \text { initial water content, \% } \\ \text { MLP } & - \text { multi-layer perceptron } \\ \text { MR } & - \text { moisture ratio } \\ P & - \text { pressure, bar } \\ R^{2} & - \text { coefficient of determination } \\ \text { RMSE } & - \text { root mean squared error } \\ \text { RSM } & - \text { response surface methodology } \\ \text { SVMR } & - \text { support vector machine regression } \\ t & - \text { drying time, min } \\ T & - \text { temperature, }{ }^{\circ} \mathrm{C} \\ \chi & - \text { chi-square }\end{array}$

\section{References \\ Literatura}

1. A. Djebli, S. Hanini, O. Badaoui, M. Boumahdi, A new approach to the thermodynamics study of drying tomatoes in mixed solar dryer, Sol. Energy 193 (2019) 164-174, doi: https://doi.org/10.1016/j.solener.2019.09.057.

2. C. M. Mcloughlin, W. A. M. McMinn, T. R. A. Magee, Microwave Drying of Pharmaceutical Powders, Food Bioprod. Process 78 (2000) 90-96, doi: https://doi. org/10.1205/096030800532798.

3. C. M. McLoughlin, W. A. M. McMinn, T. R. A. Magee, Micro-
wave-Vacuum Drying of Pharmaceutical Powders, Dry Technol. 21 (2003) 1719-1733, doi: https://doi.org/10.1081/ DRT-120025505.

4. G. Farrel, W. A. M. McMinn, T. R. A. Magee, Microwave-vacuum drying kinetics of pharmaceutical powders, Dry Technol. 23 (2005) 2131-2146, doi: https://doi. org/10.1080/07373930500212354.

5. T. Ttayagarajan, M. Ponnavaikko, J. Shanmugam, R. C. Panda, P. G. Rao, Artificial Neural Networks: Principle and Application To Model Based Control of Drying Systems - a Review, Dry Technol. 16 (1998) 931-966, doi: https://doi. org/10.1080/07373939808917449.

6. M. Aghbashlo, S. Hosseinpour, A. S. Mujumdar, Application of Artificial Neural Networks (ANNs) in Drying Technology: A Comprehensive Review, Dry Technol. 33 (2015) 13971462, doi: https://doi.org/10.1080/07373937.2015.103628 8.

7. V. Martínez-Martínez, J. Gomez-Gil, T. S. Stombaugh, M. D. Montross, J. M. Aguiar, Moisture Content Prediction in the Switchgrass (Panicum virgatum) Drying Process Using Artificial Neural Networks, Dry Technol. 33 (2015) 1708-1719, doi: https://doi.org/10.1080/07373937.2015.1005228.

8. E. A Zanaty, Support Vector Machines (SVMs) versus Multilayer Perception (MLP) in data classification, Egypt Informatics J. 13 (2012) 177-183, doi: https://doi.org/10.1016/j. eij.2012.08.002.

9. B. Ameri, S. Hanini, A. Benhamou, D. Chibane, Comparative approach to the performance of direct and indirect solar drying of sludge from sewage plants, experimental and theoretical evaluation, Sol. Energy 159 (2018) 722-732, doi: https://doi.org/10.1016/j.solener.2017.11.032.

10. M. Parti, Selection of Mathematical Models for Drying Grain in Thin-Layers, J. Agric. Eng. Res. 54 (1993) 339-352, doi: https://doi.org/10.1006/jaer.1993.1026.

11. M. Özdemir, Y. Onur Devres, The thin layer drying characteristics of hazelnuts during roasting, J. Food Eng. 42 (1999) 225-233, doi: https://doi.org/10.1016/S02608774(99)00126-0.

12. O. Badaoui, S. Hanini, A. Djebli, B. Haddad, A. Benhamou, Experimental and modelling study of tomato pomace waste drying in a new solar greenhouse: Evaluation of new drying models, Renew. Energy 133 (2019) 144-155, doi: https:// doi.org/10.1016/j.renene.2018.10.020.

13. J. L. Parry, Mathematical modelling and computer simulation of heat and mass transfer in agricultural grain drying: A review, J. Agric. Eng. Res. 32 (1985) (1985) 1-29, doi: https:// doi.org/10.1016/0021-8634(85)90116-7.

14. A. Mujumdar, Handbook of Industrial Drying, New York and Basel, 1987.

15. G. E. Page, Factors Influencing the Maximum Rates of Air Drying Shelled Corn in Thin layers (1949).

16. D. G. Overhults, G. M. White, H. E. Hamilton, I. J. Ross, Drying soybeans with heated airn Trans ASAE 16 (1973) 112113, doi: https://doi.org/10.13031/2013.37459.

17. S. M. Hendorson, S. Pabis, Grain Drying Theory (I) Temperature Effect on Drying Coefficient, J. Agric. Eng. Res. 6 (1961) 169-174.

18. A. Yagcioglu, A. Degirmencioglu, F. Cagatay, Drying characteristic of laurel leaves under different conditions, in: Proceedings of the $7^{\text {th }}$ International Congress on Agricultural Mechanization and Energy, Faculty of Agriculture, Cukurova University, Adana, Turkey, 1999, pp. 565-569.

19. S. M. Henderson, Progress in developing the thin layer drying equation, Trans ASAE 17 (1974) 1167-1172, doi: https:// doi.org/10.13031/2013.37052. 
20. D. Hutchinson, L. Otten, Thin-layer air drying of soybeans and white beans. Int. J. Food Sci. Technol. 18 (2007) 507-522, doi: https://doi.org/10.1111/j.1365-2621.1983. tb00292.x.

21. C. Y. Wang, R. P. Singh, A single layer drying equation for rough rice, ASAE paper 8-3001, ASAE, St. Joseph, MI, 1978.

22. A. S. Kassem, Comparative studies on thin layer drying models for wheat, in: $13^{\text {th }}$ international congress on agricultural engineering, 1998, pp. 2-6.

23. L. R. Verma, R. A. Bucklin, J. B. Endan, F. T. Wratten, Effects of drying air parameters on rice drying models, Trans. ASAE 28 (1985) 296-301, doi: https://doi.org/10.13031/2013.32245.

24. V. T. Karathanos, Determination of water content of dried fruits by drying kinetics, J. Food Eng. 39 (1999) 337-344, doi: https://doi.org/10.1016/S0260-8774(98)00132-0.

25. L. M. Diamante, P. A. Munro, Mathematical modelling of hot air drying of sweet potato slices, Int. J. Food Sci. Technol. 26 (1991) 99-109, doi: https://doi. org/10.1111/j.1365-2621.1991.tb01145.x.

26. L. M. Diamante, P. A. Munro, Mathematical modelling of the thin layer solar drying of sweet potato slices, Sol Energy 51 (1993) 271-276, doi: https://doi.org/10.1016/0038092X(93)90122-5.

27. A. Midilli, H. Kucuk, Z. Yapar, A new model for single-layer drying, Dry Technol. 20 (2002) 1503-1513, doi: https://doi. org/10.1081/DRT-120005864.

28. V. Demir, T. Gunhan, A. K. Yagcioglu, Mathematical modelling of convection drying of green table olives, Biosyst. Eng. 98 (2007) 47-53, doi: https://doi.org/10.1016/j.biosystemseng.2007.06.011.

29. O. Corzo, N. Bracho, A. Pereira, A. Vásquez, Weibull distribution for modeling air drying of coroba slices, LWT Food Sci. Technol. 41 (2008) 2023-2028, doi: https://doi. org/10.1016/j.lwt.2008.01.002.

30. C. L. Hii, C. L. Law, M. Cloke, Modeling using a new thin layer drying model and product quality of cocoa, J. Food. Eng. 90 (2009) 191-198, doi: https://doi.org/10.1016/j. jfoodeng.2008.06.022.

31. J.-W. Bai, H.-W. Xiao, H.-L. Ma, C.-S. Zhou, Artificial Neural Network Modeling of Drying Kinetics and Color Changes of Ginkgo Biloba Seeds during Microwave Drying Process, J. Food. Qual. 2018 (2018), doi: https://doi. org/10.1155/2018/3278595.
32. J. Crank, The mathematics of diffusion, Oxford University Press, 1979.

33. A. Djebli, S. Hanini, O. Badaoui, B. Haddad, A. Benhamou, Modeling and comparative analysis of solar drying behavior of potatoes, Renew. Energy 145 (2020) 1494-1506, doi: https://doi.org/10.1016/j.renene.2019.07.083.

34. N. J. Thakor, S. Sokhansanj, F. W. Sosulski, S. Yannacopoulos, Mass and dimensional changes of single canola kernels during drying, J. Food. Eng. 40 (1999) 153-160, doi: https://doi. org/10.1016/S0260-8774(99)00042-4.

35. M. N. Ramesh, W. Wolf, D. Tevini, G. Jung, Influence of processing parameters on the drying of spice paprika, J. FOod. Eng. 49 (2001) 63-72, doi: https://doi.org/10.1016/S02608774(00)00185-0.

36. C. Si-Moussa, S. Hanini, R. Derriche, M. Bouhedda, A. Bouzidi, Prediction of high-pressure vapor liquid equilibrium of six binary systems, carbon dioxide with six esters, using an artificial neural network model, Brazilian J. Chem. Eng. 25 (2008) 183-199, doi: https://doi.org/10.1590/S010466322008000100019.

37. A. M. Ghaedi, A. Vafaei, Applications of artificial neural networks for adsorption removal of dyes from aqueous solution: A review, Adv. Colloid Interface Sci. 245 (2017) 20-39 . doi: https://doi.org/10.1016/j.cis.2017.04.015.

38. A. P. Plumb, R. C. Rowe, P. York, M. Brown, Optimisation of the predictive ability of artificial neural network (ANN) models: A comparison of three ANN programs and four classes of training algorithm, Eur. J. Pharm. Sci. 25 (2005) 395-405, doi: https://doi.org/10.1016/j.ejps.2005.04.010.

39. S. Haykin, Neural Networks: A Comprehensive Foundation, $1^{\text {st }}$ Ed. Prentice Hall PTR, Upper Saddle River, 1994, NJ, USA.

40. V. Vapnik, The nature of statistical learning theory, Springer Science \& Business Media, 2000.

41. T.-M. Huang, V. Kecman, I. Kopriva, Kernel based algorithms for mining huge data sets, Springer, 2006.

42. H.-T. Lin, C.-J. Lin, A study on sigmoid kernels for SVM and the training of non-PSD kernels by SMO-type methods, Neural Comput. 3 (2003) 1-32.

43. W. Wang, Z. Xu, W. Lu, X. Zhang, Determination of the spread parameter in the Gaussian kernel for classification and regression, Neurocomp. 55 (2003) 643-663, doi: https://doi. org/10.1016/S0925-2312(02)00632-X. 


\section{SAŽETAK \\ Umjetna inteligencija i matematičko modeliranje kinetike sušenja farmaceutskog praha \\ Sonia Keskes, ${ }^{a, b^{*}}$ Salah Hanini, ${ }^{a}$ Mohamed Hentablia,b i Mammar Laidi ${ }^{\mathrm{b}}$}

Cilj rada je modeliranje kinetike sušenja farmaceutskog praha s aktivnim sastojkom Candesartan Cilexetil. Kinetika je izvedena u vakuumskoj sušilici pri različitim temperaturama, tlaku, početnoj masi i sadržaju vode. Proučavan je utjecaj nekih radnih parametara na vrijeme sušenja. Modeliranje vremena sušenja temeljilo se na primjeni eksperimentalne metode dizajna. Dobiveni podatci prilagođeni su pomoću 17 poluempirijskih modela, jednog predloženog, statičkog ANN i DA SVMR, pregrupirajući svu proučavanu kinetiku. Predloženi model i model DA SVMR pokazali su se kao najprikladniji za opisivanje kinetike sušenja.

Ključne riječi

Algoritam Dragonfly, regresija potpornih vektora (DA_SVMR), umjetna neuronska mreža (ANN), matematičko modeliranje, kinetika sušenja, vakuumsko sušenje, Candesartan Cilexetil

a Laboratory Quality Control, Physico-Chemical

Izvorni znanstveni rad Department, SAIDAL of Médéa, Alžir

${ }^{b}$ Laboratory of Biomaterials and Transport Prispjelo 25. kolovoza 2019. Phenomena (LBMPT), Faculty of Technology, University Yahia Fares of Médéa, Alžir Prihvaćeno 12. prosinca 2019. 


\section{Supplementary data}

Table S1 - Experimental data

\begin{tabular}{|c|c|c|c|c|}
\hline$m / g$ & $X_{0} / \%$ & $p /$ bar & $\mathrm{T} /{ }^{\circ} \mathrm{C}$ & Time $/ \mathrm{min}$ \\
\hline 0.5 & 10 & 0.4 & 40 & 15 \\
\hline 1 & 10 & 0.4 & 40 & 16 \\
\hline 1.5 & 10 & 0.4 & 40 & 21 \\
\hline 0.5 & 15 & 0.4 & 40 & 16 \\
\hline 1 & 15 & 0.4 & 40 & 17 \\
\hline 1.5 & 15 & 0.4 & 40 & 22 \\
\hline 0.5 & 20 & 0.4 & 40 & 17 \\
\hline 1 & 20 & 0.4 & 40 & 20 \\
\hline 1.5 & 20 & 0.4 & 40 & 24 \\
\hline 0.5 & 10 & 0.6 & 40 & 24 \\
\hline 1 & 10 & 0.6 & 40 & 26 \\
\hline 1.5 & 10 & 0.6 & 40 & 30 \\
\hline 0.5 & 15 & 0.6 & 40 & 24 \\
\hline 1 & 15 & 0.6 & 40 & 27 \\
\hline 1.5 & 15 & 0.6 & 40 & 30 \\
\hline 0.5 & 20 & 0.6 & 40 & 25 \\
\hline 1 & 20 & 0.6 & 40 & 28 \\
\hline 1.5 & 20 & 0.6 & 40 & 34 \\
\hline 0.5 & 10 & 0.8 & 40 & 30 \\
\hline 1 & 10 & 0.8 & 40 & 35 \\
\hline 1.5 & 10 & 0.8 & 40 & 38 \\
\hline 0.5 & 15 & 0.8 & 40 & 32 \\
\hline 1 & 15 & 0.8 & 40 & 35 \\
\hline 1.5 & 15 & 0.8 & 40 & 40 \\
\hline 0.5 & 20 & 0.8 & 40 & 30 \\
\hline 1 & 20 & 0.8 & 40 & 35 \\
\hline 1.5 & 20 & 0.8 & 40 & 42 \\
\hline 0.5 & 10 & 0.4 & 50 & 10 \\
\hline 1 & 10 & 0.4 & 50 & 10 \\
\hline 1.5 & 10 & 0.4 & 50 & 12 \\
\hline 0.5 & 15 & 0.4 & 50 & 10 \\
\hline 1 & 15 & 0.4 & 50 & 12 \\
\hline 1.5 & 15 & 0.4 & 50 & 15 \\
\hline 0.5 & 20 & 0.4 & 50 & 12 \\
\hline 1 & 20 & 0.4 & 50 & 12 \\
\hline 1.5 & 20 & 0.4 & 50 & 15 \\
\hline 0.5 & 10 & 0.6 & 50 & 13 \\
\hline 1 & 10 & 0.6 & 50 & 15 \\
\hline 1.5 & 10 & 0.6 & 50 & 19 \\
\hline 0.5 & 15 & 0.6 & 50 & 15 \\
\hline 1 & 15 & 0.6 & 50 & 17 \\
\hline 1.5 & 15 & 0.6 & 50 & 22 \\
\hline
\end{tabular}

\begin{tabular}{|c|c|c|c|c|}
\hline $\mathrm{m} / \mathrm{g}$ & $X_{0} / \%$ & $p /$ bar & $\mathrm{T} /{ }^{\circ} \mathrm{C}$ & Time / min \\
\hline 0.5 & 20 & 0.6 & 50 & 14 \\
\hline 1 & 20 & 0.6 & 50 & 17 \\
\hline 1.5 & 20 & 0.6 & 50 & 25 \\
\hline 0.5 & 10 & 0.8 & 50 & 18 \\
\hline 1 & 10 & 0.8 & 50 & 21 \\
\hline 1.5 & 10 & 0.8 & 50 & 27 \\
\hline 0.5 & 15 & 0.8 & 50 & 19 \\
\hline 1 & 15 & 0.8 & 50 & 23 \\
\hline 1.5 & 15 & 0.8 & 50 & 28 \\
\hline 0.5 & 20 & 0.8 & 50 & 22 \\
\hline 1 & 20 & 0.8 & 50 & 25 \\
\hline 1.5 & 20 & 0.8 & 50 & 30 \\
\hline 0.5 & 10 & 0.4 & 60 & 4 \\
\hline 1 & 10 & 0.4 & 60 & 6 \\
\hline 1.5 & 10 & 0.4 & 60 & 7 \\
\hline 0.5 & 15 & 0.4 & 60 & 6 \\
\hline 1 & 15 & 0.4 & 60 & 7 \\
\hline 1.5 & 15 & 0.4 & 60 & 9 \\
\hline 0.5 & 20 & 0.4 & 60 & 7 \\
\hline 1 & 20 & 0.4 & 60 & 9 \\
\hline 1.5 & 20 & 0.4 & 60 & 12 \\
\hline 0.5 & 10 & 0.6 & 60 & 10 \\
\hline 1 & 10 & 0.6 & 60 & 12 \\
\hline 1.5 & 10 & 0.6 & 60 & 15 \\
\hline 0.5 & 15 & 0.6 & 60 & 10 \\
\hline 1 & 15 & 0.6 & 60 & 13 \\
\hline 1.5 & 15 & 0.6 & 60 & 16 \\
\hline 0.5 & 20 & 0.6 & 60 & 11 \\
\hline 1 & 20 & 0.6 & 60 & 15 \\
\hline 1.5 & 20 & 0.6 & 60 & 18 \\
\hline 0.5 & 10 & 0.8 & 60 & 13 \\
\hline 1 & 10 & 0.8 & 60 & 14 \\
\hline 1.5 & 10 & 0.8 & 60 & 20 \\
\hline 0.5 & 15 & 0.8 & 60 & 14 \\
\hline 1 & 15 & 0.8 & 60 & 16 \\
\hline 1.5 & 15 & 0.8 & 60 & 22 \\
\hline 0.5 & 20 & 0.8 & 60 & 15 \\
\hline 1 & 20 & 0.8 & 60 & 17 \\
\hline 1.5 & 20 & 0.8 & 60 & 24 \\
\hline 1 & 15 & 0.6 & 50 & 11 \\
\hline 1 & 15 & 0.6 & 50 & 11.5 \\
\hline 1 & 15 & 0.6 & 50 & 11.8 \\
\hline
\end{tabular}


Table S2 - Statistical analysis of models after optimisation for kinetics of mass $0.5 \mathrm{~g}$

\begin{tabular}{|c|c|c|c|c|c|c|c|c|c|c|c|c|}
\hline \multirow[b]{2}{*}{$\mathrm{N}^{\circ}$} & \multirow[b]{2}{*}{$\mathrm{T} /{ }^{\circ} \mathrm{C}$} & \multicolumn{7}{|c|}{ Parameters } & \multicolumn{4}{|c|}{ Parameters' statistics } \\
\hline & & k & $\mathrm{n}$ & $\mathrm{L}$ & $\mathrm{a}$ & C & $\mathrm{b}$ & $k_{1}$ & $R^{2}$ & $X^{2} \cdot 10^{4}$ & $\mathrm{RMSE} \cdot 10^{3}$ & $\begin{array}{c}\chi^{2} \text { Moy } \\
\cdot 10^{4}\end{array}$ \\
\hline$\frac{\overline{0}}{2}$ & $\begin{array}{l}60 \\
50 \\
40\end{array}$ & $\begin{array}{l}1.00950 \\
0.58525 \\
0.21941\end{array}$ & & & & & & & $\begin{array}{l}0.99201 \\
0.99473 \\
0.99508\end{array}$ & $\begin{array}{l}7.90000 \\
6.40000 \\
6.60000\end{array}$ & $\begin{array}{l}26.7715 \\
23.6930 \\
23.7770\end{array}$ & 6.96666 \\
\hline$\frac{\text { ำ }}{\mathrm{o}}$ & $\begin{array}{l}60 \\
50 \\
40\end{array}$ & $\begin{array}{l}2.96210 \\
1.16277 \\
0.32181\end{array}$ & $\begin{array}{l}0.06009 \\
0.44067 \\
0.79820\end{array}$ & & & & & & $\begin{array}{l}0.99994 \\
0.99902 \\
0.99665\end{array}$ & $\begin{array}{c}0.06400 \\
1.33000 \\
5.19000\end{array}$ & $\begin{array}{l}2.25900 \\
9.99200 \\
19.2480\end{array}$ & 2.19467 \\
\hline$\frac{m}{i}$ & $\begin{array}{l}60 \\
50 \\
40\end{array}$ & $\begin{array}{l}343553 \\
1.40770 \\
0.24164\end{array}$ & $\begin{array}{l}0.07050 \\
0.44074 \\
0.79821\end{array}$ & & & & & & $\begin{array}{l}0.99993 \\
0.99902 \\
0.99665\end{array}$ & $\begin{array}{l}0.07200 \\
1.33000 \\
5.18700\end{array}$ & $\begin{array}{l}2.40700 \\
9.99100 \\
19.2480\end{array}$ & 2.19633 \\
\hline$\frac{ \pm}{0}$ & $\begin{array}{l}60 \\
50 \\
40\end{array}$ & $\begin{array}{l}1.00944 \\
0.58475 \\
0.21898\end{array}$ & & & $\begin{array}{l}0.99991 \\
0.99858 \\
0.99746\end{array}$ & & & & $\begin{array}{l}0.992013 \\
0.994713 \\
0.995070\end{array}$ & $\begin{array}{l}8.95800 \\
7.48200 \\
7.90000\end{array}$ & $\begin{array}{l}26.7710 \\
23.6881 \\
23.7579\end{array}$ & 8.11333 \\
\hline$\frac{10}{\frac{10}{2}}$ & $\begin{array}{l}60 \\
50 \\
40\end{array}$ & $\begin{array}{l}1.39257 \\
0.65172 \\
0.24304\end{array}$ & & & $\begin{array}{l}0.96995 \\
0.97306 \\
0.97029\end{array}$ & $\begin{array}{l}0.03005 \\
0.02643 \\
0.03062\end{array}$ & & & $\begin{array}{l}0.999907 \\
0.999017 \\
0.998739\end{array}$ & $\begin{array}{l}0.11250 \\
1.58400 \\
2.39800\end{array}$ & $\begin{array}{l}2.80570 \\
9.95100 \\
11.7050\end{array}$ & 1.36483 \\
\hline$\frac{0}{i}$ & $\begin{array}{l}60 \\
50 \\
40\end{array}$ & $\begin{array}{l}0.01319 \\
6.41236 \\
0.01005\end{array}$ & & & $\begin{array}{l}0.03919 \\
0.70633 \\
0.03897\end{array}$ & & $\begin{array}{l}0.96080 \\
0.29347 \\
0.96208\end{array}$ & $\begin{array}{l}29.7562 \\
0.21737 \\
0.24654\end{array}$ & $\begin{array}{l}0.999843 \\
0.998210 \\
0.998752\end{array}$ & $\begin{array}{l}0.22100 \\
3.69000 \\
3.16500\end{array}$ & $\begin{array}{l}3.63800 \\
13.5820 \\
11.6470\end{array}$ & 2.35866 \\
\hline$\frac{1}{8}$ & $\begin{array}{l}60 \\
50 \\
40\end{array}$ & $\begin{array}{l}1.62293 \\
1.17203 \\
0.36834\end{array}$ & & & $\begin{array}{l}0.48935 \\
0.38176 \\
0.43495\end{array}$ & & & & $\begin{array}{l}0.992159 \\
0.995988 \\
0.996594\end{array}$ & $\begin{array}{l}8.79000 \\
5.66000 \\
5.35000\end{array}$ & $\begin{array}{l}26.5124 \\
20.6030 \\
19.5510\end{array}$ & 6.60000 \\
\hline$\frac{\infty}{\dot{0}}$ & $\begin{array}{l}60 \\
50 \\
40\end{array}$ & & & & $\begin{array}{l}-0.1108 \\
-0.1307 \\
-0.1042\end{array}$ & & $\begin{array}{l}0.00254 \\
0.00364 \\
0.00251\end{array}$ & & $\begin{array}{l}0.486520 \\
0.662605 \\
0.896880\end{array}$ & $\begin{array}{l}943.130 \\
693.300 \\
190.400\end{array}$ & $\begin{array}{l}274.683 \\
228.040 \\
116.620\end{array}$ & 608.943 \\
\hline$\frac{0}{\frac{0}{2}}$ & $\begin{array}{l}60 \\
50 \\
40\end{array}$ & $\begin{array}{l}1.47787 \\
0.04875 \\
0.01129\end{array}$ & & & $\begin{array}{l}0.96598 \\
0.05916 \\
0.03853\end{array}$ & & $\begin{array}{l}0.00459 \\
14.7323 \\
21.7276\end{array}$ & & $\begin{array}{l}0.999938 \\
0.999374 \\
0.998743\end{array}$ & $\begin{array}{l}0.07370 \\
1.01000 \\
2.39000\end{array}$ & $\begin{array}{l}2.27110 \\
7.94400 \\
11.6877\end{array}$ & 1.15790 \\
\hline$\frac{0}{\frac{0}{5}}$ & $\begin{array}{l}60 \\
50 \\
40\end{array}$ & $\begin{array}{l}0.00678 \\
0.04908 \\
0.24631\end{array}$ & & & $\begin{array}{l}0.03402 \\
0.05943 \\
0.96113\end{array}$ & & $\begin{array}{l}1.47723 \\
0.71887 \\
0.01000\end{array}$ & & $\begin{array}{l}0.999939 \\
0.999374 \\
0.998750\end{array}$ & $\begin{array}{l}0.07370 \\
1.01000 \\
2.38000\end{array}$ & $\begin{array}{l}2.27120 \\
7.94400 \\
11.6600\end{array}$ & 1.15456 \\
\hline$\frac{\overline{5}}{8}$ & $\begin{array}{l}60 \\
50 \\
40\end{array}$ & $\begin{array}{l}1.70000 \\
0.76113 \\
0.48475\end{array}$ & $\begin{array}{l}1.69800 \\
0.05219 \\
0.05767\end{array}$ & & $\begin{array}{l}302.800 \\
1.03881 \\
2.45151\end{array}$ & $\begin{array}{l}-301.79 \\
0.06281 \\
0.14451\end{array}$ & $\begin{array}{l}0.03400 \\
-0.1011 \\
-1.5959\end{array}$ & $\begin{array}{l}0.00600 \\
10.4958 \\
6.31183\end{array}$ & $\begin{array}{l}0.999938 \\
0.999335 \\
0.999672\end{array}$ & $\begin{array}{l}0.12980 \\
2.68600 \\
2.49000\end{array}$ & $\begin{array}{l}2.27880 \\
8.19400 \\
5.96900\end{array}$ & 1.76860 \\
\hline$\frac{N}{\frac{N}{8}}$ & $\begin{array}{l}60 \\
50 \\
40\end{array}$ & $\begin{array}{l}26.3579 \\
52.8952 \\
4.90130\end{array}$ & & $\begin{array}{l}5.10993 \\
9.51087 \\
4.73103\end{array}$ & $\begin{array}{l}0.99991 \\
0.99859 \\
0.99746\end{array}$ & & & & $\begin{array}{l}0.978015 \\
0.994712 \\
0.995067\end{array}$ & $\begin{array}{l}38.4700 \\
8.97800 \\
9.87800\end{array}$ & $\begin{array}{l}49.0300 \\
23.6880 \\
23.7579\end{array}$ & 19.1087 \\
\hline$\frac{n}{\frac{n}{8}}$ & $\begin{array}{l}60 \\
50 \\
40\end{array}$ & $\begin{array}{l}4.07829 \\
7.52002 \\
15.3607\end{array}$ & $\begin{array}{l}0.06009 \\
0.44106 \\
0.79837\end{array}$ & $\begin{array}{r}14.3089 \\
-8.3049 \\
11.2579\end{array}$ & & & & & $\begin{array}{l}0.999940 \\
0.999020 \\
0.996650\end{array}$ & $\begin{array}{l}0.07290 \\
1.59700 \\
6.48400\end{array}$ & $\begin{array}{l}2.25900 \\
9.99200 \\
19.2480\end{array}$ & 2.71796 \\
\hline$\frac{ \pm}{\frac{ \pm}{8}}$ & $\begin{array}{l}60 \\
50 \\
40\end{array}$ & $\begin{array}{l}2.74000 \\
0.98277 \\
0.23840\end{array}$ & $\begin{array}{l}0.11871 \\
0.58101 \\
0.97951\end{array}$ & & $\begin{array}{l}0.99999 \\
0.99999 \\
1.00032\end{array}$ & & $\begin{array}{l}0.00039 \\
0.00083 \\
0.00115\end{array}$ & & $\begin{array}{l}0.999987 \\
0.999878 \\
0.998491\end{array}$ & $\begin{array}{l}0.01770 \\
0.24530 \\
3.83000\end{array}$ & $\begin{array}{l}1.03300 \\
3.50262 \\
12.8100\end{array}$ & 1.36433 \\
\hline$\frac{10}{\frac{10}{5}}$ & $\begin{array}{l}60 \\
50 \\
40\end{array}$ & $\begin{array}{l}2.97398 \\
0.95635 \\
10.9206\end{array}$ & $\begin{array}{l}0.26738 \\
0.65197 \\
-2.1013\end{array}$ & & $\begin{array}{l}0.97264 \\
0.97998 \\
0.97772\end{array}$ & & $\begin{array}{l}0.02736 \\
0.01999 \\
1.00002\end{array}$ & & $\begin{array}{l}0.999980 \\
0.999825 \\
0.999430\end{array}$ & $\begin{array}{l}0.02750 \\
0.35200 \\
1.44400\end{array}$ & $\begin{array}{l}1.28560 \\
4.19400 \\
7.86700\end{array}$ & 0.60783 \\
\hline$\frac{0}{\frac{0}{0}}$ & $\begin{array}{l}60 \\
50 \\
40\end{array}$ & & & & $\begin{array}{l}0.00000 \\
0.71087 \\
4.13854\end{array}$ & & $\begin{array}{l}0.07251 \\
0.44091 \\
0.79829\end{array}$ & & $\begin{array}{l}0.999928 \\
0.999017 \\
0.996646\end{array}$ & $\begin{array}{l}0.07610 \\
1.33100 \\
5.18700\end{array}$ & $\begin{array}{l}02.4679 \\
9.99167 \\
19.2480\end{array}$ & 2.19803 \\
\hline$\frac{1}{\frac{1}{0}}$ & $\begin{array}{l}60 \\
50 \\
40\end{array}$ & $\begin{array}{l}18.5381 \\
33.1056 \\
14.3446\end{array}$ & $\begin{array}{l}-66.470 \\
-1.7241 \\
-30.922\end{array}$ & & $\begin{array}{l}-3.0000 \\
-2.9990 \\
-3.0000\end{array}$ & & $\begin{array}{l}8.59710 \\
14.5340 \\
-21.132\end{array}$ & $\begin{array}{l}-24.724 \\
-25.313 \\
-35.931\end{array}$ & $\begin{array}{l}0.989727 \\
0.963562 \\
0.863038\end{array}$ & $\begin{array}{l}18.6590 \\
108.060 \\
621.447\end{array}$ & $\begin{array}{l}30.54491 \\
63.65846 \\
133.2502\end{array}$ & 249.389 \\
\hline 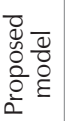 & $\begin{array}{l}60 \\
50 \\
40\end{array}$ & $\begin{array}{l}1.54228 \\
2.27393 \\
0.11375\end{array}$ & $\begin{array}{l}-0.2183 \\
-0.1441 \\
0.63649\end{array}$ & $\begin{array}{l}30.3013 \\
6250.99 \\
0.01893\end{array}$ & $\begin{array}{l}-29.301 \\
-6249.9 \\
0.21960\end{array}$ & $\begin{array}{c}-30.273 \\
-62509.7 \\
0.76148\end{array}$ & & & $\begin{array}{l}0.999999 \\
0.999999 \\
0.999986\end{array}$ & $\begin{array}{l}0.00050 \\
0.00016 \\
0.04984\end{array}$ & $\begin{array}{l}0.15890 \\
0.07780 \\
1.19340\end{array}$ & 0.01683 \\
\hline
\end{tabular}


Table S3 - Statistical analysis of models after optimisation for kinetics of mass $1.0 \mathrm{~g}$

\begin{tabular}{|c|c|c|c|c|c|c|c|c|c|c|c|c|}
\hline \multirow{2}{*}{$\mathrm{N}^{\circ}$} & \multirow{2}{*}{$\mathrm{T} /{ }^{\circ} \mathrm{C}$} & \multicolumn{7}{|c|}{ Parameters } & \multicolumn{4}{|c|}{ Parameters' statistics } \\
\hline & & k & $\mathrm{n}$ & $\mathrm{L}$ & $\mathrm{a}$ & $\mathrm{C}$ & $\mathrm{b}$ & $k_{1}$ & $R^{2}$ & $X^{2} \cdot 10^{4}$ & RMSE $\cdot 10^{3}$ & $\begin{array}{c}\chi^{2} \text { Moy } \\
\cdot 10^{4}\end{array}$ \\
\hline$\frac{\overline{0}}{\Sigma}$ & $\begin{array}{l}60 \\
50 \\
40\end{array}$ & $\begin{array}{l}0.57420 \\
0.40960 \\
0.19040\end{array}$ & & & & & & & $\begin{array}{l}0.9757935 \\
0.9938633 \\
0.9931500\end{array}$ & $\begin{array}{l}24.089000 \\
7.4651400 \\
9.1061100\end{array}$ & $\begin{array}{l}46.562750 \\
25.557775 \\
27.937855\end{array}$ & 13,5535 \\
\hline$\frac{\text { N }}{\mathrm{D}}$ & $\begin{array}{l}60 \\
50 \\
40\end{array}$ & $\begin{array}{l}1.38804 \\
0.60358 \\
0.16538\end{array}$ & $\begin{array}{l}0.28728 \\
0.70260 \\
1.07338\end{array}$ & & & & & & $\begin{array}{l}0.9986904 \\
0.9951707 \\
0.9934320\end{array}$ & $\begin{array}{l}1.3211926 \\
6.6016495 \\
10.639189\end{array}$ & $\begin{array}{l}10.280827 \\
22.251376 \\
27.567047\end{array}$ & 6,18735 \\
\hline$\sum^{\frac{m}{0}}$ & $\begin{array}{l}60 \\
50 \\
40\end{array}$ & $\begin{array}{l}3.13099 \\
0.48840 \\
0.18710\end{array}$ & $\begin{array}{l}0.28728 \\
0.70041 \\
1.07036\end{array}$ & & & & & & $\begin{array}{l}0.9986905 \\
0.9951688 \\
0.9934280\end{array}$ & $\begin{array}{l}1.3211926 \\
6.6014938 \\
10.639200\end{array}$ & $\begin{array}{l}10.280827 \\
22.251113 \\
27.567072\end{array}$ & 6,18729 \\
\hline$\frac{⿱ 亠}{0}$ & $\begin{array}{l}60 \\
50 \\
40\end{array}$ & $\begin{array}{l}0.57284 \\
0.40921 \\
0.19088\end{array}$ & & & $\begin{array}{l}0.99660 \\
0.99870 \\
1.00310\end{array}$ & & & & $\begin{array}{l}0.9756502 \\
0.9938498 \\
0.9932042\end{array}$ & $\begin{array}{l}27.086944 \\
8.7064904 \\
10.908389\end{array}$ & $\begin{array}{l}46.550569 \\
25.553606 \\
27.913629\end{array}$ & 15,5673 \\
\hline$\frac{10}{0}$ & $\begin{array}{l}60 \\
50 \\
40\end{array}$ & $\begin{array}{l}0.72530 \\
0.45052 \\
0.20382\end{array}$ & & & $\begin{array}{l}0.95193 \\
0.97065 \\
0.98468\end{array}$ & $\begin{array}{l}0.04742 \\
0.03007 \\
0.02097\end{array}$ & & & $\begin{array}{c}0.9930065 \\
0.998900 \\
0.9945524\end{array}$ & $\begin{array}{c}8.0194220 \\
1.757170 \\
10.571182\end{array}$ & $\begin{array}{l}23.693027 \\
10.479656 \\
24.577786\end{array}$ & 6,78259 \\
\hline$\frac{0}{0}$ & $\begin{array}{l}60 \\
50 \\
40\end{array}$ & $\begin{array}{l}0.07419 \\
0.32485 \\
0.22379\end{array}$ & & & $\begin{array}{l}0.15499 \\
0.74511 \\
1.23319\end{array}$ & & $\begin{array}{l}0.84501 \\
0.25481 \\
-0.2332\end{array}$ & $\begin{array}{l}1.23812 \\
8.76288 \\
55.6124\end{array}$ & $\begin{array}{l}0.9984894 \\
0.9942884 \\
0.9940565\end{array}$ & $\begin{array}{l}2.0414590 \\
11.980690 \\
16.208470\end{array}$ & $\begin{array}{l}11.067409 \\
24.475185 \\
26.356178\end{array}$ & 10.0769 \\
\hline$\frac{1}{8}$ & $\begin{array}{l}60 \\
50 \\
40\end{array}$ & $\begin{array}{l}1.10189 \\
0.66397 \\
0.24238\end{array}$ & & & $\begin{array}{l}0.38117 \\
0.44944 \\
1.64200\end{array}$ & & & & $\begin{array}{l}0.9790939 \\
0.9947597 \\
0.9935664\end{array}$ & $\begin{array}{l}23.215310 \\
7.3438680 \\
10.536810\end{array}$ & $\begin{array}{l}43.095532 \\
23.468917 \\
27.434096\end{array}$ & 13.6987 \\
\hline$\frac{\infty}{0}$ & $\begin{array}{l}60 \\
50 \\
40\end{array}$ & & & & $\begin{array}{l}-0.1066 \\
-0.1256 \\
-0.1014\end{array}$ & & $\begin{array}{l}0.00239 \\
0.00343 \\
0.00240\end{array}$ & & $\begin{array}{l}0.5926412 \\
0.7396349 \\
0.9260606\end{array}$ & $\begin{array}{l}713.28190 \\
513.16500 \\
134.39210\end{array}$ & $\begin{array}{l}238.87769 \\
196.18201 \\
097.97669\end{array}$ & 453.613 \\
\hline$\frac{0}{0}$ & $\begin{array}{l}60 \\
50 \\
40\end{array}$ & $\begin{array}{l}0.07417 \\
0.02116 \\
0.19627\end{array}$ & & & $\begin{array}{l}0.15499 \\
0.04457 \\
0.99626\end{array}$ & & $\begin{array}{l}16.6897 \\
21.9289 \\
-0.3483\end{array}$ & & $\begin{array}{l}0.9984894 \\
0.9990097 \\
0.9947460\end{array}$ & $\begin{array}{l}1.7498220 \\
1.5786410 \\
10.076900\end{array}$ & $\begin{array}{l}11.067408 \\
09.933030 \\
23.996336\end{array}$ & 4.46845 \\
\hline$\frac{0}{\frac{0}{0}}$ & $\begin{array}{l}60 \\
50 \\
40\end{array}$ & $\begin{array}{l}0.07419 \\
0.02118 \\
38.2547\end{array}$ & & & $\begin{array}{l}0.15500 \\
0.04458 \\
-0.2284\end{array}$ & & $\begin{array}{l}1.23825 \\
0.46411 \\
0.22299\end{array}$ & & $\begin{array}{l}0.9984895 \\
0.9990097 \\
0.9940547\end{array}$ & $\begin{array}{l}1.7498225 \\
1.5786409 \\
12.155539\end{array}$ & $\begin{array}{l}11.067411 \\
9.9330286 \\
26.355308\end{array}$ & 5.16133 \\
\hline$\frac{\bar{\sigma}}{\frac{0}{0}}$ & $\begin{array}{l}60 \\
50 \\
40\end{array}$ & $\begin{array}{l}0.08540 \\
7.04544 \\
9.25560\end{array}$ & $\begin{array}{l}28.7820 \\
1.10393 \\
0.06130\end{array}$ & & $\begin{array}{c}0.1786 \\
-4.6764 \\
-7.7260\end{array}$ & $\begin{array}{l}-2.9433 \\
5.57460 \\
0.16670\end{array}$ & $\begin{array}{l}3.76470 \\
0.10171 \\
8.55910\end{array}$ & $\begin{array}{l}2.76795 \\
0.06104 \\
0.67906\end{array}$ & $\begin{array}{l}0.9983610 \\
0.9998417 \\
0.9998145\end{array}$ & $\begin{array}{l}3.3294477 \\
0.6327511 \\
1.4459233\end{array}$ & $\begin{array}{l}11.540273 \\
3.9772828 \\
4.5448924\end{array}$ & 1.80271 \\
\hline $\begin{array}{l}\frac{N}{5} \\
\frac{0}{2}\end{array}$ & $\begin{array}{l}60 \\
50 \\
40\end{array}$ & $\begin{array}{l}21.6121 \\
5.10324 \\
10.7013\end{array}$ & & $\begin{array}{l}6.14331 \\
3.53141 \\
7.48749\end{array}$ & $\begin{array}{l}0.99661 \\
0.99900 \\
1.00305\end{array}$ & & & & $\begin{array}{l}0.9756492 \\
0.9938499 \\
0.9932042\end{array}$ & $\begin{array}{l}30.956500 \\
10.447787 \\
13.635487\end{array}$ & $\begin{array}{l}46.550566 \\
25.553606 \\
27.913629\end{array}$ & 18.3465 \\
\hline$\frac{n}{\frac{n}{0}}$ & $\begin{array}{l}60 \\
50 \\
40\end{array}$ & $\begin{array}{l}10.6222 \\
31.5809 \\
19.5385\end{array}$ & $\begin{array}{l}0.28728 \\
0.69923 \\
1.07052\end{array}$ & $\begin{array}{l}34.5316 \\
16.8878 \\
-9.2660\end{array}$ & & & & & $\begin{array}{l}0.9986905 \\
0.9951677 \\
0.9934282\end{array}$ & $\begin{array}{l}1.5099343 \\
7.9219097 \\
13.298900\end{array}$ & $\begin{array}{l}10.280827 \\
22.251278 \\
27.567038\end{array}$ & 7.57691 \\
\hline$\frac{ \pm}{\frac{\Xi}{0}}$ & $\begin{array}{l}60 \\
50 \\
40\end{array}$ & $\begin{array}{l}1.37930 \\
0.46620 \\
0.11080\end{array}$ & $\begin{array}{l}0.29210 \\
0.91790 \\
1.31630\end{array}$ & & $\begin{array}{l}0.9999 \\
1.0003 \\
1.0006\end{array}$ & & $\begin{array}{l}4.9 \mathrm{e}-05 \\
0.00120 \\
0.00150\end{array}$ & & $\begin{array}{l}0.9986923 \\
0.9980212 \\
0.9974192\end{array}$ & $\begin{array}{l}1.7586778 \\
3.9730422 \\
6.7423556\end{array}$ & $\begin{array}{l}10.272325 \\
14.094400 \\
16.998768\end{array}$ & 4.15803 \\
\hline$\frac{10}{\frac{1}{0}}$ & $\begin{array}{l}60 \\
50 \\
40\end{array}$ & $\begin{array}{l}1.38973 \\
4.07950 \\
34.0290\end{array}$ & $\begin{array}{l}0.27807 \\
-2.3422 \\
-2.6286\end{array}$ & & $\begin{array}{l}1.00352 \\
-0.9732 \\
-0.9695\end{array}$ & & $\begin{array}{l}-0.0035 \\
1.00002 \\
1.00004\end{array}$ & & $\begin{array}{l}0.9986930 \\
0.9994937 \\
0.9992954\end{array}$ & $\begin{array}{l}1.758458 \\
1.011582 \\
1.831652\end{array}$ & $\begin{array}{l}10.271684 \\
07.111898 \\
08.859987\end{array}$ & 1.53389 \\
\hline$\frac{0}{\frac{0}{0}}$ & $\begin{array}{l}60 \\
50 \\
40\end{array}$ & & & & $\begin{array}{l}0.31939 \\
2.05081 \\
5.34697\end{array}$ & & $\begin{array}{l}0.28728 \\
0.70220 \\
1.07345\end{array}$ & & $\begin{array}{l}0.9986905 \\
0.9951704 \\
0.9934321\end{array}$ & $\begin{array}{l}1.3211926 \\
6.6015899 \\
10.639202\end{array}$ & $\begin{array}{l}10.280827 \\
22.251275 \\
27.567063\end{array}$ & 6.18732 \\
\hline$\frac{1}{\frac{1}{0}}$ & $\begin{array}{l}60 \\
50 \\
40\end{array}$ & $\begin{array}{l}37.5710 \\
6.27910 \\
55.3890\end{array}$ & $\begin{array}{l}-24.848 \\
7.13831 \\
5.83590\end{array}$ & & $\begin{array}{l}-2.9999 \\
-3.0000 \\
-3.0000\end{array}$ & & $\begin{array}{l}44.1689 \\
5.68002 \\
35.9444\end{array}$ & $\begin{array}{l}-59.683 \\
-2.6171 \\
11.7388\end{array}$ & $\begin{array}{l}0.9484470 \\
0.8948138 \\
0.7980636\end{array}$ & $\begin{array}{l}95.89114 \\
319.5577 \\
933.3840\end{array}$ & $\begin{array}{l}069.24274 \\
109.46878 \\
163.30379\end{array}$ & 449.611 \\
\hline 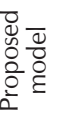 & $\begin{array}{l}60 \\
50 \\
40\end{array}$ & $\begin{array}{l}0.13528 \\
2.26934 \\
0.03280\end{array}$ & $\begin{array}{c}0.0999 \\
-0.3611 \\
0.46227\end{array}$ & $\begin{array}{l}0.02158 \\
2.56788 \\
-0.0495\end{array}$ & $\begin{array}{l}0.18695 \\
-1.5682 \\
0.19397\end{array}$ & $\begin{array}{l}0.79141 \\
-2.5370 \\
0.85555\end{array}$ & & & $\begin{array}{l}0.9990387 \\
0.9994023 \\
0.9998458\end{array}$ & $\begin{array}{l}1.5524646 \\
1.5960408 \\
0.6016198\end{array}$ & $\begin{array}{l}8.8104048 \\
7.7363771 \\
4.1459784\end{array}$ & 1.25004 \\
\hline
\end{tabular}


Table S4 - Statistical analysis of models after optimisation for kinetics of mass $1.5 \mathrm{~g}$

\begin{tabular}{|c|c|c|c|c|c|c|c|c|c|c|c|c|}
\hline \multirow{2}{*}{$\mathrm{N}^{\circ}$} & \multirow{2}{*}{$\mathrm{T} /{ }^{\circ} \mathrm{C}$} & \multicolumn{7}{|c|}{ Parameters } & \multicolumn{4}{|c|}{ Parameters' statistics } \\
\hline & & k & $\mathrm{n}$ & $\mathrm{L}$ & $\mathrm{a}$ & $\mathrm{C}$ & b & $k_{1}$ & $R^{2}$ & $X^{2} \cdot 10^{4}$ & $\mathrm{RMSE} \cdot 10^{3}$ & $\begin{array}{c}\chi^{2} \text { Moy } \\
\cdot 10^{4}\end{array}$ \\
\hline$\frac{\bar{g}}{\Sigma}$ & $\begin{array}{l}60 \\
50 \\
40\end{array}$ & $\begin{array}{l}0.46845 \\
0.22781 \\
0.13612\end{array}$ & & & & & & & $\begin{array}{l}0.9813946 \\
0.9957000 \\
0.9894636\end{array}$ & $\begin{array}{l}18.538795 \\
5.3597061 \\
11.743705\end{array}$ & $\begin{array}{l}40.8471739 \\
21.6558140 \\
32.3092078\end{array}$ & 11.8807 \\
\hline$\frac{\text { ำ }}{\text { ¿ }}$ & $\begin{array}{l}60 \\
50 \\
40\end{array}$ & $\begin{array}{l}1.04669 \\
0.25528 \\
0.10860\end{array}$ & $\begin{array}{c}0.39700 \\
0.930061 .10446\end{array}$ & & & & & & $\begin{array}{l}0.9993345 \\
0.9960066 \\
0.9905198\end{array}$ & $\begin{array}{l}0.6758412 \\
5.6785650 \\
12.485455\end{array}$ & $\begin{array}{l}07.3530469 \\
20.6371600 \\
31.1623327\end{array}$ & 6.27995 \\
\hline$\frac{n}{\check{z}}$ & $\begin{array}{l}60 \\
50 \\
40\end{array}$ & $\begin{array}{l}1.12183 \\
0.23036 \\
0.13397\end{array}$ & $\begin{array}{l}0.39703 \\
0.92995 \\
1.10449\end{array}$ & & & & & & $\begin{array}{l}0.9993345 \\
0.9960064 \\
0.9905199\end{array}$ & $\begin{array}{l}0.6758412 \\
5.6785688 \\
12.485454\end{array}$ & $\begin{array}{l}07.3530469 \\
20.6371670 \\
31.1623312\end{array}$ & 6.27996 \\
\hline$\frac{ \pm}{\frac{ \pm}{2}}$ & $\begin{array}{l}60 \\
50 \\
40\end{array}$ & $\begin{array}{l}0.46625 \\
0.22762 \\
0.13733\end{array}$ & & & $\begin{array}{l}0.99417 \\
0.99917 \\
1.01018\end{array}$ & & & & $\begin{array}{l}0.9812247 \\
0.9956939 \\
0.9897934\end{array}$ & $\begin{array}{l}20.814043 \\
6.2517927 \\
13.263556\end{array}$ & $\begin{array}{l}40.8059244 \\
21.6537399 \\
32.1186843\end{array}$ & 13.4431 \\
\hline$\frac{10}{8}$ & $\begin{array}{l}60 \\
50 \\
40\end{array}$ & $\begin{array}{l}0.56329 \\
0.24649 \\
0.14769\end{array}$ & & & $\begin{array}{l}0.95400 \\
0.97800 \\
0.99160\end{array}$ & $\begin{array}{l}0.04432 \\
0.02649 \\
0.02353\end{array}$ & & & $\begin{array}{l}0.9957362 \\
0.9982553 \\
0.9915638\end{array}$ & $\begin{array}{l}4.9064327 \\
2.8990586 \\
12.296491\end{array}$ & $\begin{array}{l}18.5324118 \\
13.4607266 \\
28.6315573\end{array}$ & 6.70066 \\
\hline$\frac{0}{8}$ & $\begin{array}{l}60 \\
50 \\
40\end{array}$ & $\begin{array}{l}10.8551 \\
0.22418 \\
0.14244\end{array}$ & & & & $\begin{array}{l}0.72040 \\
0.98370 \\
1.01000\end{array}$ & $\begin{array}{l}0.27960 \\
0.01610 \\
0.00420\end{array}$ & $\begin{array}{l}0.12810 \\
6.06950 \\
-0.0530\end{array}$ & $\begin{array}{l}0.9975516 \\
0.9957006 \\
0.9920060\end{array}$ & $\begin{array}{l}3.3617210 \\
9.3405126 \\
13.961182\end{array}$ & $\begin{array}{l}14.2022272 \\
21.6107757 \\
27.8499769\end{array}$ & 8.88781 \\
\hline$\frac{1}{8}$ & $\begin{array}{l}60 \\
50 \\
40\end{array}$ & $\begin{array}{l}0.97947 \\
0.32543 \\
0.18308\end{array}$ & & & $\begin{array}{l}0.35323 \\
0.50489 \\
1.72034\end{array}$ & & & & $\begin{array}{l}0.9858449 \\
0.9966917 \\
0.9909437\end{array}$ & $\begin{array}{l}15.677124 \\
04.674416 \\
12.159485\end{array}$ & $\begin{array}{l}35.4142612 \\
18.7238137 \\
30.7528486\end{array}$ & 10.8370 \\
\hline$\frac{\infty}{\check{g}}$ & $\begin{array}{l}60 \\
50 \\
40\end{array}$ & & & & $\begin{array}{l}-0.1059 \\
-0.1128 \\
-0.0758\end{array}$ & & $\begin{array}{l}0.00237 \\
0.00292 \\
0.00135\end{array}$ & & $\begin{array}{l}0.6357407 \\
0.8912357 \\
0.9228045\end{array}$ & $\begin{array}{l}631.9006 \\
196.9385 \\
116.2001\end{array}$ & $\begin{array}{l}224.83783 \\
121.53349 \\
095.06727\end{array}$ & 315.013 \\
\hline$\frac{9}{\frac{0}{0}}$ & $\begin{array}{l}60 \\
50 \\
40\end{array}$ & $\begin{array}{l}0.06627 \\
0.24661 \\
0.14065\end{array}$ & & & $\begin{array}{l}0.13790 \\
0.97020 \\
0.99610\end{array}$ & & $\begin{array}{l}11.1872 \\
0.02354 \\
-0.3788\end{array}$ & & $\begin{array}{l}0.9992025 \\
0.9982166 \\
0.9915330\end{array}$ & $\begin{array}{l}0.9244435 \\
2.9376166 \\
11.988655\end{array}$ & $\begin{array}{l}08.0443175 \\
13.5499459 \\
28.2708975\end{array}$ & 5.28357 \\
\hline$\frac{0}{\frac{0}{8}}$ & $\begin{array}{l}60 \\
50 \\
40\end{array}$ & $\begin{array}{l}0.74089 \\
0.24642 \\
8.89885\end{array}$ & & & $\begin{array}{l}0.86228 \\
0.97068 \\
-0.2329\end{array}$ & & $\begin{array}{l}0.06615 \\
0.00497 \\
0.16338\end{array}$ & & $\begin{array}{l}0.9992026 \\
0.9982167 \\
0.9923170\end{array}$ & $\begin{array}{l}0.9 .24450 \\
2.9375557 \\
12.004392\end{array}$ & $\begin{array}{l}08.0443478 \\
13.5498057 \\
28.2894465\end{array}$ & 5.28880 \\
\hline$\frac{5}{\bar{\delta}}$ & $\begin{array}{l}60 \\
50 \\
40\end{array}$ & $\begin{array}{l}0.06710 \\
10.3220 \\
0.04400\end{array}$ & $\begin{array}{l}0.76000 \\
0.39900 \\
8.27400\end{array}$ & & $\begin{array}{l}0.13960 \\
-0.3992 \\
0.17050\end{array}$ & $\begin{array}{l}0.89700 \\
1.21200 \\
-1.1500\end{array}$ & $\begin{array}{l}-0.0366 \\
0.18702 \\
1.97990\end{array}$ & $\begin{array}{l}7.74190 \\
0.07920 \\
0.30952\end{array}$ & $\begin{array}{l}0.9991935 \\
0.9997255 \\
0.9999635\end{array}$ & $\begin{array}{l}1.6369448 \\
1.1409889 \\
0.1073742\end{array}$ & $\begin{array}{l}8.09183484 \\
5.34085378 \\
1.89186188\end{array}$ & 0.96177 \\
\hline$\frac{N}{\frac{N}{5}}$ & $\begin{array}{l}60 \\
50 \\
40\end{array}$ & $\begin{array}{l}29.2536 \\
39.3837 \\
18.2750\end{array}$ & & $\begin{array}{l}07.9210 \\
13.1540 \\
11.5360\end{array}$ & $\begin{array}{l}0.99416 \\
0.99917 \\
1.01018\end{array}$ & & & & $\begin{array}{l}0.9812245 \\
0.9956939 \\
0.9897934\end{array}$ & $\begin{array}{l}23.787478 \\
7.5021512 \\
15.474148\end{array}$ & $\begin{array}{l}40.8059245 \\
21.6537398 \\
32.1186843\end{array}$ & 15.5879 \\
\hline$\frac{m}{5}$ & $\begin{array}{l}60 \\
50 \\
40\end{array}$ & $\begin{array}{l}16.6379 \\
13.7452 \\
17.0476\end{array}$ & $\begin{array}{l}0.39700 \\
0.93030 \\
1.10460\end{array}$ & $\begin{array}{l}32.5698 \\
8.52112 \\
9.86304\end{array}$ & & & & & $\begin{array}{l}0.9993345 \\
0.9960069 \\
0.9905201\end{array}$ & $\begin{array}{l}0.7723900 \\
6.8142844 \\
14.566360\end{array}$ & $\begin{array}{l}7.35304693 \\
20.6371697 \\
31.1623277\end{array}$ & 7.38435 \\
\hline$\frac{+}{\frac{ \pm}{\delta}}$ & $\begin{array}{l}60 \\
50 \\
40\end{array}$ & $\begin{array}{l}0.96127 \\
0.22315 \\
0.07694\end{array}$ & $\begin{array}{l}0.46234 \\
1.03635 \\
1.29870\end{array}$ & & $\begin{array}{l}0.99999 \\
1.00154 \\
1.00249\end{array}$ & & $\begin{array}{l}0.00058 \\
0.00122 \\
0.00127\end{array}$ & & $\begin{array}{l}0.9998629 \\
0.9981711 \\
0.9966723\end{array}$ & $\begin{array}{l}0.1846843 \\
3.8155463 \\
5.9000675\end{array}$ & $\begin{array}{l}3.32882221 \\
13.8122162 \\
18.1047377\end{array}$ & 3.30010 \\
\hline$\frac{10}{\frac{10}{8}}$ & $\begin{array}{l}60 \\
50 \\
40\end{array}$ & $\begin{array}{l}0.96590 \\
3.72424 \\
18.4958\end{array}$ & $\begin{array}{l}0.50234 \\
-1.4873 \\
-1.9563\end{array}$ & & $\begin{array}{l}0.97810 \\
-1.0050 \\
-0.9791\end{array}$ & & $\begin{array}{l}0.02190 \\
0.99990 \\
1.00010\end{array}$ & & $\begin{array}{l}0.9998227 \\
0.9997064 \\
0.9998572\end{array}$ & $\begin{array}{l}0.2390348 \\
0.6108268 \\
0.2517842\end{array}$ & $\begin{array}{l}3.78709460 \\
5.52642221 \\
3.74005528\end{array}$ & 0.36722 \\
\hline$\frac{0}{5}$ & $\begin{array}{l}60 \\
50 \\
40\end{array}$ & & & & $\begin{array}{l}0.89139 \\
4.34098 \\
7.46416\end{array}$ & & $\begin{array}{l}0.39703 \\
0.93036 \\
1.10490\end{array}$ & & $\begin{array}{l}0.9993345 \\
0.9960070 \\
0.9905210\end{array}$ & $\begin{array}{l}0.6758412 \\
5.6785736 \\
12.485453\end{array}$ & $\begin{array}{l}07.3530469 \\
20.6371756 \\
31.1623299\end{array}$ & 6.27996 \\
\hline$\frac{n}{\bar{c}}$ & $\begin{array}{l}60 \\
50 \\
40\end{array}$ & $\begin{array}{l}21.162 \\
14.384 \\
3.1304\end{array}$ & $\begin{array}{l}16.6610 \\
-20.030 \\
-16.240\end{array}$ & & $\begin{array}{l}-3.0000 \\
-3.0000 \\
-3.0000\end{array}$ & & $\begin{array}{l}31.6190 \\
-0.4020 \\
-23.870\end{array}$ & $\begin{array}{l}-17.492 \\
-2.5160 \\
29.0168\end{array}$ & $\begin{array}{l}0.9262146 \\
0.6664565 \\
0.6334615\end{array}$ & $\begin{array}{l}0038.3632 \\
1112.6545 \\
0939.6110\end{array}$ & $\begin{array}{l}083.175480 \\
204.265800 \\
204.353830\end{array}$ & 696.876 \\
\hline 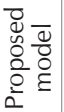 & $\begin{array}{l}60 \\
50 \\
40\end{array}$ & $\begin{array}{l}0.20559 \\
0.15549 \\
0.04200\end{array}$ & $\begin{array}{l}-0.8131 \\
0.63293 \\
0.57492\end{array}$ & $\begin{array}{l}0.73959 \\
0.01756 \\
-0.0090\end{array}$ & $\begin{array}{l}0.26039 \\
0.42539 \\
0.19635\end{array}$ & $\begin{array}{l}-0.7145 \\
0.55674 \\
0.81270\end{array}$ & & & $\begin{array}{l}0.9998256 \\
0.9997259 \\
0.9999832\end{array}$ & $\begin{array}{l}0.2821034 \\
0.7601747 \\
0.0371114\end{array}$ & $\begin{array}{l}3.75568484 \\
5.33915274 \\
1.28428953\end{array}$ & 0.35980 \\
\hline
\end{tabular}

